\title{
A Passage to India: Quantifying Internal and External Barriers to Trade
}

Van Leemput, Eva

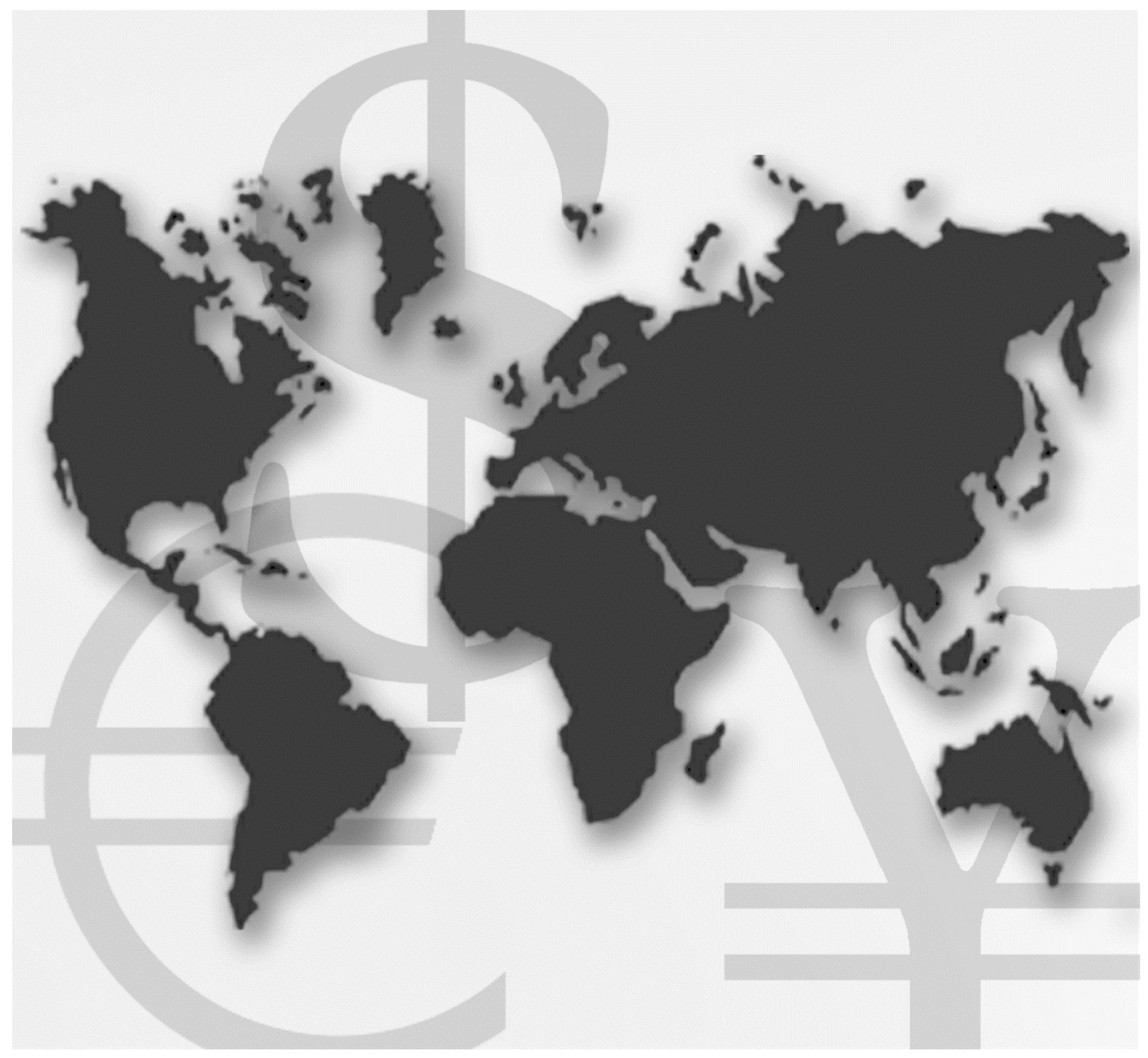

\section{International Finance Discussion Papers}

Board of Governors of the Federal Reserve System

Number 1185

November 2016 


\author{
Board of Governors of the Federal Reserve System \\ International Finance Discussion Papers
}

Number 1185

December 2016

\title{
A Passage to India: Quantifying Internal and External Barriers to Trade
}

\author{
Eva Van Leemput
}

NOTE: International Finance Discussion Papers are preliminary materials circulated to stimulate discussion and critical comment. References to International Finance Discussion Papers (other than an acknowledgment that the writer has had access to unpublished material) should be cleared with the author or authors. Recent IFDPs are available on the Web at www. federalreserve. gov/pubs/ifdp/. This paper can be downloaded without charge from the Social Science Research Network electronic library at wWW.ssrn.com. 


\title{
A Passage to India: Quantifying Internal and External Barriers to Trade
}

\author{
Eva Van Leemput*
}

\begin{abstract}
This paper quantifies the size of internal versus external trade barriers and assesses the impact on trade and welfare. I develop a quantitative multi-sector international trade model featuring nonhomothetic preferences in which states trade both domestically and internationally. I discipline the model using rich micro data on price dispersion as well as foreign and domestic trade flows at the Indian state level. I find that (1) state-based price data predict internal trade flows well; (2) internal trade barriers make up $40 \%$ of the total trade cost on average, but vary substantially by state depending on the distance to the closest port; and (3) the welfare impacts of domestic integration are substantial: reducing trade barriers across states to the U.S. level increases welfare by more $(13 \%)$ than fully eliminating international import barriers $(7 \%)$.
\end{abstract}

Keywords: Internal Trade Barriers, External Trade Barriers, Welfare, India JEL classification: F13, F14, O18, O24.

*The author is a staff economist in the Division of International Finance, Board of Governors of the Federal Reserve System, Washington, D.C. 20551 U.S.A. The views in this paper are solely the responsibility of the authors and should not be interpreted as reflecting the views of the Board of Governors of the Federal Reserve System or of any other person associated with the Federal Reserve System. Contact: eva.vanleemput@frb.gov.

I would like to thank Joseph Kaboski, Wyatt Brooks, Kevin Donovan, Timothy Kehoe, and Nelson Mark for valuable comments, suggestions, and support. I also thank seminar participants at Notre Dame, the Federal Reserve Bank of Chicago, the Federal Reserve Bank of Minneapolis, the IMF, USITC, the Federal Reserve Board, Toulouse School of Economics, Goethe, Williams College, UC Louvain, VU Amsterdam, Florida International U, Delaware, Vienna, Georgetown SFS for helpful comments and suggestions. 


\section{Introduction}

International barriers to trade, and the benefits from reducing them, have been both a policy and research focus for decades. But recently, policy has focused more on domestic trade barriers and their role in improving the economy. For example, in 2014, the World Bank increased their financing commitments to roads, bridges, energy, and other infrastructure projects by $45 \%$, to $\$ 24$ billion, compared to 2013. However, the question remains whether domestic integration has a larger effect on trade and welfare than reducing international trade barriers.

This paper quantitatively addresses two main questions: (1) how large are internal versus external trade barriers in India? and (2) how large are the welfare impacts of internal compared to external integration? I contribute to the literature in two ways. First, whereas the literature has mostly focused on estimating the impact of decreasing either internal or external trade barriers, this paper quantifies both barriers in a unified framework and compares the welfare impacts of relaxing them. Second, this framework allows for a richer deconstruction of different types of internal trade barriers. With respect to foreign market access, I model an additional barrier-an internal barrier of reaching an international port. With respect to domestic trade, the model deconstructs two types of trade barriers in India: across-state and rural-urban within state. Therefore, as a secondary question I ask: does India have more to gain from better integrating regions across or within states?

I develop a quantitative, two-sector, international trade model that explicitly accounts for internal trade barriers. I model India as a multistate country in which each state trades both with other states and with the rest of the world. Each state consists of a rural and an urban region, which produces agricultural and manufacturing goods, respectively, and consumers have nonhomothetic preferences for these goods. The model's innovation is twofold. The first is to include domestic trade barriers in an international trade framework. More specifically, I model two types of domestic trade barriers in India: a trade barrier across Indian states and one between the urban and rural region within an Indian state. The second is to allow states within India to have different international port access. Standard international trade models implicitly assume that the entire population has free access to an international port. In this paper, however, I allow for Indian states with and 
without international ports. This implies that states without an international port face an additional domestic trade barrier when trading internationally: the cross-state barrier to move goods to and from the nearest port.

To map the model to the Indian economy, I combine two rich micro-level datasets: (1) the State Movement/Flows of Goods and (2) the Foreign Trade Statistics for India. Together, they detail good-specific trade flows bilaterally between Indian states and internationally between each Indian state and the world. On the export side, it includes the state of origin, the destination for cross-state trade, and the port of exit for international trade. For imports, it includes the state of origin in the case of cross-state trade and the port of entry for international trade. These data overcome two major common issues, namely, distinguishing domestic from international trade flows and identifying the specific port of international trade.

To discipline the trade barriers in the model both within and across states, I use data containing measures of price dispersion of wholesale agricultural prices published by the Data Portal of India. This data set consists of daily state-, market-, and variety-specific wholesale prices of 50 different agricultural goods across 1,831 markets in all Indian states. Using a no-arbitrage argument, I compute cross-state trade barriers for all agricultural prices observed in urban markets, and I find they are five times larger than in the United States, which is around the same magnitude as estimated using micro evidence for other developing countries (Atkin and Donaldson, 2016). To discipline the rural-urban trade barriers in each state, I use the same no-arbitrage argument using the price variation across urban and rural markets within a state. I find that the median rural-urban trade barrier is almost double the size of the median cross-state trade barrier in the United States. Finally, I compute international trade barriers by matching state-wise international import shares for agriculture and manufacturing.

Using price dispersion to discipline trade barriers instead of direct measures such as distance has the advantage of encompassing more than just infrastructure barriers. In fact, I find that the price dispersion is highly correlated with distance but also with non-infrastructural barriers such as the level of corruption across Indian states, the arduousness of the tax administration, and the tax level. In addition, I show that price dispersion both across and within states predicts internal trade flows well. 
First, I find that, on average, internal trade barriers in India, which include both the rural-urban and cross-state barriers, make up $40 \%$ of the total trade barrier, but there is a large heterogeneity across states: the $90-10$ percentile is $70-13 \%$. Most of the heterogeneity is driven by port versus non-port states, where internal barriers make up $17 \%$ and $51 \%$ of the total trade barrier, respectively.

Second, I find larger welfare gains from domestic integration in India than international; reducing trade barriers between Indian states to the U.S. level increases welfare by $13 \%$ compared to a welfare gain of $7 \%$ when fully eliminating international import barriers. Finally, deconstructing internal trade barriers in India, I find larger welfare gains associated with removing cross-state barriers than rural-urban barriers. To summarize, I find that (1) India has more to gain from becoming more internally integrated than from fully eliminating international import barriers and (2) the largest internal gains come from better connecting Indian states.

\section{Related Literature}

This paper builds on the seminal model of geography and trade of Eaton and Kortum (2002) and on Fieler's (2011) two-sector extension, and it contributes to two main literatures. The first examines the size, nature, and impact of international trade barriers in explaining international trade patterns. Waugh (2010) studies the sizes of trade barriers across developed and developing countries. He finds that trade frictions between rich and poor countries are systematically asymmetric, with poor countries facing higher costs to export relative to rich countries. Tombe (2015) also estimates larger trade costs for developing countries, but argues that these countries face especially large trade costs in agriculture. Regarding the components of international trade barriers, Limão and Venables (1999) find that infrastructure is an important determinant of transport costs, especially for landlocked countries. They estimate that halving transport costs would increase trade volume by a factor of five. Hummels and Schaur (2013) estimate that time in transit poses a large international trade barrier. They find that each day in transit is equivalent to an ad valorem tariff of 0.6 to $2.3 \%$. The focus of this literature is on border costs. My paper complements these works by disentangling border costs from intracountry costs and assessing their respective impact on trade 
and welfare.

The second is an emerging literature examining the role of internal trade costs on the production and trade patterns in developing countries. Based on detailed micro data, Donaldson (2016), Atkin and Donaldson (2016), Allen (2014), Asturias et al. (2016), and Adamopoulos (2011) quantify the size and nature of intracountry trade frictions for developing countries but do not compare them to international trade frictions. Other work has estimated the regional effects of differential market access within countries on the gains from trade. Behrens et al. (2006) find that for regions that are "geographically disadvantaged" with high intracountry trade costs, being remote acts as a barrier to competition from abroad. Storeygard (2016) shows that regions in sub-Saharan Africa with better access to port cities benefit more from terms of trade shocks. Coçar and Fajgelbaum (2016) develop a framework for the spatial distribution of economic activity in an arbitrary topography of trade costs where products are differentiated by origin. They find that in the presence of high domestic frictions, international trade creates a partition between a commercially integrated coastal region with a high population density and an interior region where mobility is limited. Gollin and Rogerson (2014) examine the interaction of intracountry trade frictions and employment patterns between agricultural and manufacturing sectors, taking as given that developing countries import very little agriculture. My paper shows the effect of these intracountry trade frictions on international trade patterns. The distinctive aspects of this paper are the state-based domestic and international trade data and the state-based characteristics. Previous studies have differentiated intracountry trade flows, but only aggregated international trade flows. In this paper, I can distinguish international trade by state and also through which ports trade happens. As I will show, this is quantitatively important in explaining aggregate trade flows and in determining the effect of international trade policies in terms of heterogeneity across states. Moreover, this framework allows me to compare domestic and international integration and their welfare implications. The question arises, what does India have to gain from trading with the rest of the world versus becoming more integrated itself?

The remainder of the paper is organized as follows. Section 2 outlines the international trade model. Sections 3 and 4 describe the data and the quantitative analysis, respectively. Section 5 presents the results. Section 6 presents additional robustness checks. Section 7 concludes. 


\section{Model}

The model extends the Eaton-Kortum (2002) framework to include many states within a country that consist of both a rural and urban region. More concretely, I model trade between a multistate country and a second uniform country representing the rest of the world. The quantitative part is based on India and, therefore, the model is presented accordingly.

\subsection{Environment}

India consists of multiple states denoted by $s=1 \ldots S$. Each state consists of two regions, rural and urban, indexed by $r=\{R, U\}$, where $R$ denotes the rural and $U$ the urban region. This economy produces two types of goods, agriculture and manufacturing, indexed by $g \in\{a, m\}$, where $a$ denotes agricultural and $m$ manufacturing goods. All agricultural production takes place in the rural region and all manufacturing production in the urban region $\sqrt[1]{1}$ For each good, there is a continuum of individual varieties, $j_{g}$, defined on the interval $[0,1]$. Both good types are produced with Ricardian technology and require only labor for production, which is immobile across regions and states..$^{2}$ I assume that the share of workers in rural and urban regions is $\beta_{s} \in[0,1]$ and $\left(1-\beta_{s}\right)$, respectively. Internal trade for all agricultural and manufacturing varieties in India consists of two types: (1) within-state trade between rural and urban regions and (2) cross-state trade.

\subsubsection{Consumption}

A representative household with constant relative income elasticity (CRIE) preferences, as in Fieler (2011), chooses the quantity consumed of both agricultural and manufacturing goods of variety $j_{g}$, denoted by $\left\{q\left(j_{g}\right)\right\}_{j_{g} \in[0,1]}, g \in\{a, m\}$ to maximize utility:

$$
U_{s}^{r}=\left(\frac{\sigma_{a}}{\sigma_{a}-1}\right) \int_{0}^{1}\left[q\left(j_{a}\right)^{\frac{\sigma_{a}-1}{\sigma_{a}}}\right] d j_{a}+\left(\frac{\sigma_{m}}{\sigma_{m}-1}\right) \int_{0}^{1}\left[q\left(j_{m}\right)^{\frac{\sigma_{m}-1}{\sigma_{m}}}\right] d j_{m}
$$

\footnotetext{
${ }^{1}$ This is consistent with the data: in India, on average, $69 \%$ of the population is located in the rural region, of which $91 \%$ are employed in agriculture.

${ }^{2}$ Cross-state migration is low in India. The 2001 Census reports that total cross-state migration is around $1.6 \%$, of which $43 \%$ is due to marriage. I allow for rural-urban labor mobility in Section 6.1. and I find that the qualitative results are robust.
} 
subject to

$$
\int_{0}^{1} q_{s}^{r}\left(j_{a}\right) p_{s}^{r}\left(j_{a}\right) d j_{a}+\int_{0}^{1} q_{s}^{r}\left(j_{m}\right) p_{s}^{r}\left(j_{m}\right) d j_{m}=w_{s}^{r},
$$

where $w_{s}^{r}$ is the regional wage in state $s$. The good-specific parameter $\sigma_{g}>1$ represents the elasticity of substitution across varieties. It also represents the income elasticity. Define $x_{g, s}^{r}$ as the expenditures on a good of type $g \in\{a, m\}$ in region $r$ and state $s$. Then, from the first-order conditions from the household problem, expenditures toward agriculture relative to manufacturing satisfy

$$
\frac{x_{a, s}^{r}}{x_{m, s}^{r}}=\left(\lambda_{s}^{r}\right)^{\sigma_{m}-\sigma_{a}} \frac{\left(P_{a, s}^{r}\right)^{1-\sigma_{a}}}{\left(P_{m, s}^{r}\right)^{1-\sigma_{m}}},
$$

where $\lambda_{s}^{r}$ is the Lagrange multiplier on the budget constraint and the shadow value of income. It is strictly decreasing in the consumer's total income. If $\sigma_{m}-\sigma_{a}>0$, then expenditures on agriculture relative to manufacturing, $\frac{x_{a, s}^{r}}{x_{m, s}^{r}}$, increase with $\lambda_{s}^{r}$ and, therefore, decrease with income. In other words, as a household's income increases, the percentage of spending on manufacturing goods increases relative to agricultural goods. Hence, CRIE preferences allow for consumers with different income levels to concentrate their spending on different types of goods and, therefore, allow for matching cross-country agricultural and manufacturing consumption patterns.

\subsubsection{Production}

Each region draws a good-specific productivity $z_{s}$ from a state-specific distribution for all varieties of the good produced in that region, that is, rural regions only have productivity draws for all agricultural varieties and the urban region only for all manufacturing varieties. As in Eaton and Kortum (2002), I assume this distribution is Frchet:

$$
z_{s}\left(j_{g}\right) \sim F_{s}(z)=\exp \left(-T_{g, s} z_{s}^{-\theta_{g}}\right) \quad s \in\{a, m\} .
$$

The parameter $T_{g, s}$ is state- and good-specific and governs the absolute advantage: higher values of $T_{g, s}$ indicate productivity draws from a higher mean distribution. The good-specific parameter, $\theta_{g}$, governs the comparative advantage. Higher values imply that there is a smaller range of productivity draws. For example, for a high $\theta_{a}$, agricultural productivity varies little across states, which 
implies small gains from trade. Production in both sectors has constant returns to scale (CRS). Because labor is immobile, wages are both state- and region-specific. Denoting the regional wage in state $s$ by $w_{s}^{r}$, the unit cost for good variety $j_{g}$ is

$$
\frac{w_{s}^{r}}{z_{s}\left(j_{g}\right)} \text {. }
$$

Unit costs are higher as wages increase or productivity decreases. Next, I describe the three types of trade: (1) rural-urban trade within a state, (2) cross-state trade, and (3) international trade.

\subsubsection{Rural-Urban Trade within State}

Within each state in India, production is region-specific. Hence, trade within a state occurs between the urban and rural region. I assume that consumers in the rural region can buy agricultural goods at the unit cost of agricultural production. However, if they want to buy manufacturing goods, those need to be transported from the urban to the rural region at an iceberg transportation cost, $\delta_{s}>1$. Consumers in the urban region can buy manufacturing goods at the unit cost of manufacturing production, but buying agricultural products requires the same iceberg transportation cost, $\delta_{s}$. Note that these iceberg transportation costs are state-specific and I will refer to them as rural-urban trade barriers. Given these barriers, prices for both goods are different across regions. Table 1 presents the regional prices for agricultural and manufacturing goods in state $s$.

Table 1: Prices within State

\begin{tabular}{c|cc}
\hline \hline & Agriculture & Manufacturing \\
\hline Rural & $p_{s}^{R}\left(j_{a}\right)=\frac{w_{s}^{R}}{z_{s}\left(j_{a}\right)}$ & $p_{s}^{R}\left(j_{m}\right)=\frac{w_{s}^{U} \delta_{s}}{z_{s}\left(j_{m}\right)}$ \\
Urban & $p_{s}^{U}\left(j_{a}\right)=\frac{w_{s}^{R} \delta_{s}}{z_{s}\left(j_{a}\right)}$ & $p_{s}^{U}\left(j_{m}\right)=\frac{w_{s}^{U}}{z_{s}\left(j_{m}\right)}$ \\
\hline \hline
\end{tabular}




\subsubsection{Cross-State Trade}

I also model trade across states in India. I assume that they can only trade via their urban regions at an additional cross-state iceberg transportation cost, $d_{s l}>1$, which represents the cost of importing from the urban region in state $l$ to that of state $s$. This implies that if the state of Gujarat ships rice to the state of Rajasthan, the rural region in Gujarat first needs to ship the rice to its urban region at a rural-urban trade barrier $\delta_{G}$, after which it can be shipped to the urban region of Rajasthan at a cross-state trade barrier $d_{R G}$. If the rice is consumed in the urban region of Rajasthan, the total barrier is $\delta_{G} * d_{R G}$. If the rice is consumed in the rural region of Rajasthan, it needs to be transported at an additional rural-urban trade barrier of $\delta_{R}$, and the total barrier is $\delta_{G} * d_{R G} * \delta_{R}$. This entire barrier is what I will refer to as the internal trade barrier that includes the cross-state trade barrier and the rural-urban trade barrier.

Table 2: Cross-State Trade Barriers

\begin{tabular}{cc|cc}
\hline \hline & \multicolumn{2}{|c}{ From State 1 } \\
& & Rural & Urban \\
\hline & Rural & $\delta_{1} * d_{21} * \delta_{2}$ & $\delta_{1} * d_{21}$ \\
To State 2 & Urban & $d_{21} * \delta_{2}$ & $d_{21}$ \\
& & & \\
\hline \hline
\end{tabular}

Within India, the four scenarios that can occur are detailed in Table 2, which summarizes the total trade barrier of shipping one unit of variety $j_{g}$ from state 1 to state 2 . Section 4 explains how these barriers are separately identified. This concludes the multistate economy model. Next, I describe the third type of trade: international trade.

\subsubsection{International Trade}

All Indian states not only trade with each other, but also with the rest of the world (RoW), modeled as one country. The preferences and production processes for both types of goods in the RoW are also described by (1) and (2). As is standard in the literature, international trade is subject to an 
international border iceberg transportation cost, which is good-specific and depends on whether India is the importer or exporter. ${ }^{3}$ Delivering one unit of a good-specific variety $j_{g}$ from the RoW to India requires the production of $\tau_{g, i m p}>1$ units, and delivering one unit of $j_{g}$ from India to the RoW requires the production of $\tau_{g, \exp }>1$ units.

The innovation in the model is that international trade can only occur through international ports. The trade literature typically assumes that the entire population consumes and produces at the port, whereas this paper distinguishes Indian states as having an international port or not. This is quantitatively important along two dimensions.

First, it is important for the price of imported goods. Consider an Indian state with an international port, Gujarat. If Gujarat imports rice from the RoW, it incurs a border import barrier, $\tau_{a, i m p}$. If the rice is consumed in the urban region of Gujarat, the total trade barrier is $\tau_{a, i m p}$. If the rice is consumed in the rural region, it needs to be transported at an additional rural-urban trade barrier, $\delta_{G}$, making the total trade barrier $\tau_{a, i m p} * \delta_{G}$. Now consider a non-port state, Rajasthan. If Rajasthan imports rice from the RoW, it first needs to import the good through the port of Gujarat, which is the closest port, at a border import barrier $\tau_{a, i m p}$. Then, the rice is shipped from Gujarat to Rajasthan at an additional cross-state barrier of $d_{R G}$. If the rice is consumed in the urban region of Rajasthan, the total trade barrier is $\tau_{a, i m p} * d_{R, G}$. If it is consumed in the rural region of Rajasthan, its rural-urban trade barrier, $\delta_{R}$, is incurred as well, and the total trade barrier is $\tau_{a, i m p} * d_{R G} * \delta_{R}$.

Second, it is important for the price of exported goods. Consider the same example. If Gujarat exports rice, it first needs to be transported from the rural to the urban region with a rural-urban trade barrier, $\delta_{G}$, after which it is exported with a border export barrier, $\tau_{a, \text { exp }}$, making the total trade barrier $\delta_{G} * \tau_{a, \exp }$. If Rajasthan exports rice, similarly, it first needs to be transported from the rural to the urban region with a rural-urban trade barrier, $\delta_{R}$. Rajasthan does not have an international port. Thus, the rice needs to be transported to the urban region of the nearest port, Gujarat, with a cross-state barrier, $d_{G, R}$, after which it is exported to the RoW with the border export barrier $\tau_{a, \text { exp }}$. The total trade barrier is $\delta_{R} * d_{G R} * \tau_{a, \text { exp }}$, which is weakly higher than if Rajasthan would have had an international port.

\footnotetext{
${ }^{3}$ The border trade barriers are good-specific to be consistent with Tombe (2015) and I allow for import and export costs to differ, that is, $\tau_{g, i m p} \neq \tau_{g, \exp }$ to be consistent with Waugh (2010)
} 
Thus, differential international market access affects not only import but also export prices. Moreover, a more flexible location model of consumption and production allows for heterogeneous effects on trade and welfare as a consequence of internal and external trade liberalization.

To summarize, define $D_{g, s l}^{r}$ as the total trade barrier faced in region $r$ in state $s$ for good variety $j_{g}$ imported from state $l$. $D_{g, s l}^{r}$ depends on the region of consumption: rural or urban, the type of good: agriculture or manufacturing, and whether state $s$ has an international port. Define state $t$ as a non-port state and state $s$ as its nearest port state in India. The total barriers to trading internationally for state $s$ and $t$ are summarized in Table 3, which consist of the border trade barriers and the domestic trade barriers.

Table 3: Total International Trade Barriers

\begin{tabular}{|c|c|c|c|c|c|}
\hline & & \multicolumn{2}{|c|}{ Port State $s$} & \multicolumn{2}{|c|}{ Non-Port State $t$} \\
\hline & & Agriculture & Manufacturing & Agriculture & Manufacturing \\
\hline \multirow[t]{2}{*}{ Imports } & Rural & $\delta_{s} * \tau_{a, i m p}$ & $\delta_{s} * \tau_{m, i m p}$ & $\delta_{t} * d_{t s} * \tau_{a, i m p}$ & $\delta_{t} * d_{t s} * \tau_{m, i m p}$ \\
\hline & Urban & $\tau_{a, i m p}$ & $\tau_{m, i m p}$ & $d_{t s} * \tau_{a, i m p}$ & $d_{t s} * \tau_{m, i m p}$ \\
\hline \multirow[t]{2}{*}{ Exports } & Rural & $\delta_{s} * \tau_{a, \exp }$ & $\tau_{m, \exp }$ & $\delta_{t} * d_{s t} * \tau_{a, \exp }$ & $d_{s t} * \tau_{m, e x p}$ \\
\hline & Urban & $\delta_{s} * \tau_{a, \exp }$ & $\tau_{m, \exp }$ & $\delta_{t} * d_{s t} * \tau_{a, e x p}$ & $d_{s t} * \tau_{m, \exp }$ \\
\hline
\end{tabular}

To compute trade flows, I need to define region-specific prices within states given the previously outlined trade barriers. Following the literature, I assume that markets are perfectly competitive $4^{4}$ Then, the price for good variety $j_{g}$ in region $r$ in state $s$ is

$$
p_{s}^{r}\left(j_{g}\right)=\min \left\{p_{s l}^{r}\left(j_{g}\right) ; l=1 \ldots S, R o W\right\}
$$

where $p_{s l}^{r}\left(j_{s}\right)$ varies across regions and states. Prices can be summarized as follows:

$$
p_{s}^{r}\left(j_{g}\right)=\min \left\{\frac{w_{s}^{r} D_{g, s l}^{r}}{z_{s}\left(j_{g}\right)} ; l=1 \ldots S, \text { RoW }\right\} .
$$

\footnotetext{
${ }^{4}$ Given that I discipline trade barriers using price data, any price difference in the data could also reflect market power across states. Therefore, this assumption is not as strict in the data.
} 
Note that if both rural-urban and cross-state trade barriers are set to one, the model reduces to the Eaton and Kortum (2002) model.

\subsection{Equilibrium}

For a given set of values for $\left\{\beta_{s}\right\}_{s=1 \ldots S, R o W},\left\{T_{g, s}\right\}_{s=1 \ldots S, R o W},\left\{D_{g, s l}^{r}\right\}_{s, l=1 \ldots S, R o W}$, and $\left\{L_{s}\right\}_{s=1 \ldots S, R o W}$ an equilibrium is a set of region-good-state-specific price indexes, $\left\{P_{g, s}^{r}\right\}_{s=1 \ldots S, R o W}$, region-statespecific wages, $\left\{w_{s}^{r}\right\}_{s=1 \ldots S, R o W}$, and good-specific bilateral trade flows, $\left\{X_{g, s l}\right\}_{s, l=1 \ldots S, R o W}$, where $g \in\{a, m\}$ and $r \in\{R, U\}$, such that:

1. Sector-state-specific productivities follow a Frchet distribution given by (2).

2. Consumers maximize utility (1).

3. Consumers purchase from the (trade cost inclusive) minimum cost producer.

4. Labor markets clear, that is, total shipments from state $s$ equal total production in state $s$.

All Indian states and the RoW have a continuum of individuals who inelastically supply one unit of labor. Let $L_{s}$ be the population of state $s$, of which $\beta_{s} L_{s}$ is employed in agriculture and $\left(1-\beta_{s}\right) L_{s}$ in manufacturing where $\beta_{s} \in[0,1]$. The price index associated with the objective function (1) is

$$
P_{g, s}^{r}=\left[\Gamma\left(\frac{\theta_{g}+1-\sigma_{g}}{\theta_{g}}\right)\right]^{\frac{1}{1-\sigma_{g}}}\left[\sum_{l}\left[T_{g, l}\left(w_{l}^{r} D_{g, s l}^{r}\right)^{-\theta_{g}}\right]\right]^{-\frac{1}{\theta_{g}}}
$$

where $\Gamma$ is the gamma function. A necessary condition for a finite solution is $\left(\theta_{g}+1\right)>\sigma_{g}$, $g \in\{a, m\}$. The spending of a consumer in region $r$ in state $s$ on good $g$ is

$$
x_{g, s}^{r}=\left(\lambda_{s}^{r}\right)^{-\sigma_{g}}\left(P_{g, s}^{r}\right)^{1-\sigma_{g}}
$$

where $\lambda_{s}^{r}>0$ is the region- and state-specific shadow value of income. This is implicitly determined by the budget constraint in each region: $\sum_{g \in\{a, m\}} x_{g, s}^{r}=w_{s}^{r}$. Following the methods in Eaton and Kortum (2002), the probability that state $l$ provides a good at the lowest price in region $r$ in 
state $s, \pi_{g, s l}^{r}$, is

$$
\pi_{g, s l}^{r}=\frac{x_{g, s l}^{r}}{x_{g, s}^{r}}=\frac{T_{g, l}\left(w_{l}^{r} D_{g, s l}^{r}\right)^{-\theta_{g}}}{\Phi_{g, s}^{r}}
$$

with $\Phi_{g, s}^{r}=\sum_{l} T_{g, l}\left(w_{l}^{r} D_{g, s l}^{r}\right)^{-\theta_{g}}$. To close the model I need to solve for productivity parameters $\left\{T_{g, s}\right\}$ by assuming that labor markets need to clear at given wages. Total agricultural imports in state $s$ from state $l$ are the sum of rural and urban imports:

$$
X_{a, s l}=x_{a, s l}^{R} \beta_{s} L_{s}+x_{a, s l}^{U}\left(1-\beta_{s}\right) L_{s}
$$

where $\beta_{s} \in[0,1]$ is the labor share in the rural region. Total agricultural production in state $l$ is

$$
w_{l}^{R} \beta_{l} L_{l}
$$

By equating supply to demand, I get the labor market clearing condition in the rural region:

$$
w_{l}^{R} \beta_{l} L_{l}=\sum_{l} X_{a, s l}
$$

Similarly, total manufacturing imports in state $s$ from state $l$ are the sum of rural and urban imports:

$$
X_{m, s l}=x_{m, s l}^{R} \beta_{s} L_{s}+x_{m, s l}^{U}\left(1-\beta_{s}\right) L_{s}
$$

Total manufacturing production in state $l$ is

$$
w_{l}^{U}\left(1-\beta_{l}\right) L_{l}
$$

By equating supply to demand, I get the labor market clearing condition in the urban region:

$$
w_{l}^{U}\left(1-\beta_{l}\right) L_{l}=\sum_{l} X_{m, s l}
$$

Productivity parameters $\left\{T_{g, s}\right\}_{s=1 \ldots S, R o W}$ can be computed by solving equations $(6)$ and $(8):^{5}$

This completes the statement of the model. To summarize, an economy is defined by a set of $S$ Indian states and the RoW, each with two regions: a rural and an urban region. The rural region, with a population $\beta_{s} L_{s}$, only produces agricultural goods, and the urban region, with population

\footnotetext{
${ }^{5}$ The rural region of the RoW was chosen as the numeraire.
} 
$\left(1-\beta_{s}\right) L_{s}$, only produces manufacturing goods. Each region within a state has a specific wage $w_{s}^{r}$ and a location implied by trade barriers $D_{g, s l}^{r}$. Good $g \in\{a, m\}$ is characterized by technology parameters $T_{g, s}$ and $\theta_{g}$. An equilibrium is a set of productivity parameters $\left\{T_{g, s}\right\}_{s=1 \ldots S, R o W}$ that satisfy the market clearing conditions $(6)$ and $(8)$.

\section{Indian Trade Data and Patterns}

The analysis is based on annual state-level data collected by the Directorate General of Commercial Intelligence and Statistics (DGCIS) from April 2011 to March 2012.6 There are two main datasets that describe internal and external trade flows in India. The first is the "Inter-State Movements/Flows of Goods by Rail, River and Air." This dataset contains state-level trade flows among 27 states and 3 union territories in India. The second is the "Foreign Trade Statistics of India," which contains international import and export data by country and details the ports of entry and exit in India.

\subsection{Indian Interstate Trade}

The DGCIS collects data on intra-Indian trade flows in the "Inter-State Movements/ Flows of Goods by Rail, River and Air," which provides data on the movement of goods by rail, river and air across 37 trade blocks in India for 70 good categories, which represent the main traded goods. These trade blocks contain 27 states, three union territories, and seven major port blocks.7 The trade statistics are collected through invoices of commodity consignments dispatched from each railway station to other trade blocks. Each railway and steamer company consolidates the figures with respect to the stations with which it is concerned and submits quarterly returns to the DGCIS $]^{8}$

\footnotetext{
${ }^{6}$ The data was purchased from the DGCIS (http://www.dgciskol.nic.in/).

${ }^{7}$ The 27 states are Andhra Pradesh, Assam, Arunachal Pradesh, Bihar, Chattishgarh, Goa, Gujarat, Haryana, Himachal Pradesh, Jammu and Kashmir, Jharkhand, Karnataka, Kerala, Madhya Pradesh, Maharashtra, Manipur, Meghalaya, Mizoram, Nagaland, Orissa, Punjab, Rajasthan, Tamil Nadu, Tripura, Uttarakhand, Uttar Pradesh, and West Bengal. The three union territories are Chandigarh, Delhi, and Puducherry, and the seven major port blocks are Andhra Pradesh, Gujarat, Maharashtra, Karnataka, Kerala, Tamil Nadu, and West Bengal. Figure A.1 in the online Appendix shows a map of India with the all the states and union territories included in this analysis.

${ }^{8}$ Indian states have a strong incentive to monitor these interstate flows given that they are subject to the Central Sales Tax (CST). All of the revenue accruing under the CST is collected and kept by the state in which the sale originates.
} 
These data are unique, as they provide greater insight into domestic trade flows, which are rare, especially in developing countries. A second great advantage of these data is that they allow differentiating trade between Indian states from trade between Indian states and the rest of the world. For example, I can distinguish trade flows that originate in Rajasthan and are destined for the state of Gujarat from trade flows that originate in Rajasthan and are destined for the rest of the world but pass through the ports of Gujarat. The same is true for internal versus external imports. Typically, intracountry trade data do not make this distinction.9 ${ }^{9}$ However, for the purpose of this study, it is important to be able to distinguish these trade flows and in fact, I find that doing so is quantitatively important when assessing the gains from trade liberalization.

There are, however, two caveats when using the data. The first is that interstate trade is measured in volumes and not in values, as they are not available. The second caveat is that the interstate trade data do not include trade via roads. It is known that trade via roads has become increasingly important in India over the last decade with the construction of the national highways and the Golden Quadrilateral. Hence, the trade flows via railroads are an underestimate of the total trade across Indian states $1^{10}$ In order to alleviate these two concerns, I merge these data with the portlevel data. I describe the port-level data in the next section, and then I describe the methodology of merging these two datasets.

\subsection{Indian International Trade}

The international trade data come from the "Foreign Trade Statistics of India - Principal Commodities \& Countries,". This dataset contains all Indian international exports and imports and details the ports of exit and entry, respectively. In total there are 20 seaports that account for $50 \%$ of the total trade value, eight airports that account for $23 \%$, and other ports such as Inland Container Distributions and land ports in the northern and northeastern part of India that account for 5\%. The data report the exact port for $78 \%$ of total international trade, whereas the other $22 \%$ of total international trade occurs through "other ports." Given that this still reflects a substantial part of

\footnotetext{
${ }^{9}$ For example, the Commodity Flow Survey data report trade flows across U.S. states but do not disentangle domestically produced goods from international imports or exports.

${ }^{10}$ Nevertheless, no comprehensive data on freight movement by motorized transport on roads is available, which would have indicated their importance in total trade value.
} 
total trade, I supplement the port data with two other sources of data.

The first is the "Agri Exchange" data for 2011-12. These data are from the Agricultural and Processed Food Products Export Development Authority (APEDA) in India and report more detail on the ports of exit (mainly the smaller ones) for agricultural goods. Agri Exchange, however, does not include data on the port of entry of international agricultural goods.

The second source of data comes from the "Open Government Data Platform in India," published by the Indian government. These data include port-level international import- and exportlevel data for the most important ports in India, of which 17 are not included in the Foreign Trade Statistics of India 11 When I supplement the original port data with these two datasets, I can explain $87 \%$ of total international port-level trade. The remaining $13 \%$ of port trade is distributed according to each state's import and export share for each individual good. 12

\subsection{Matching Interstate with International Data}

I now describe how I merge the interstate trade data with the international trade data. First, I match each commodity in the interstate trade data to the export and import commodity in the international trade data. As explained in Section 3.1, trade across Indian states is differentiated by exports destined for a specific state and exports going to the port of a state, for international export. This allows me to compute total international exports and imports for a specific commodity in those states with an international port.

Then, I aggregate all commodity-specific international exports and imports at the ports in the interstate trade data, that is, the ports of Andhra Pradesh, Gujarat, Karnataka, Kerala, Maharashtra, Tamil Nadu, and West Bengal. The international data describe how much is traded in values at the port level. Hence, I "price" the interstate trade data such that the total trade value at the ports from the interstate trade data amounts to the actual port-level trade values.

As an example, consider trade in wheat. The interstate trade data report trade in volumes. To convert the interstate trade volumes for wheat to values, I use the international trade information.

\footnotetext{
${ }^{11}$ The reason why I do not use these port data as the main data is timing. The data are for 2012-13, which do not coincide with the years from the interstate data: 2011-12. When I supplement the original data using this data source, I assume the fraction of total trade each port represents is constant across 2011-12 and 2012-13.

${ }^{12}$ The concentration of smaller ports is correlated with the existence of a large port and thus, international trade.
} 
More specifically, I aggregate the total amount of wheat transported to all Indian ports for international export. This needs to add up to the total port-level export value for wheat, which is obtained from the international trade data. I then price wheat trade in India such that total port trade (volume*price) at all port blocks adds up to the port value in the international trade data. I do this for each individual commodity in the interstate trade dataset.

This alleviates the two issues discussed earlier. First, all trade volume are converted to value by matching the port values. Second, the concern that trade via roads is not included in the interstate data is alleviated, as I aggregate up the interstate data to match the international trade flows. One underlying assumption is that trade via roads is highly correlated with trade via railroads. To provide some evidence for this, I correlate the density of railway networks within each state with that of road networks. I find that that the rail and road densities are highly positively correlated, with a correlation coefficient of 0.9013

\subsection{Trade Patterns}

\subsubsection{International Trade}

$76 \%$ of India's international trade goes through 21 main ports: 14 seaports and 7 airports. Figure 1 shows their location. Clearly, the landlocked states in the northern and northeastern regions of India are the most remote from these major ports. In addition, Figure 1 shows the population in each state. It shows that a large fraction $(50 \%)$ of the population lives in states without access to an international port. This is important, as these patterns are also reflected in the states' international trade openness.

The top panel in Table 4 shows the international trade openness for agriculture and manufacturing. Import and export openness are defined as total international imports and exports, respectively, divided by total sectoral production. Overall, India trades little agriculture and most of the international trade is in manufacturing. Agricultural imports are especially low, at $3 \%$ of total agricultural production.

\footnotetext{
${ }^{13}$ Source: The Ministry of Statistics and Programme Implementation in India (MOSPI).
} 


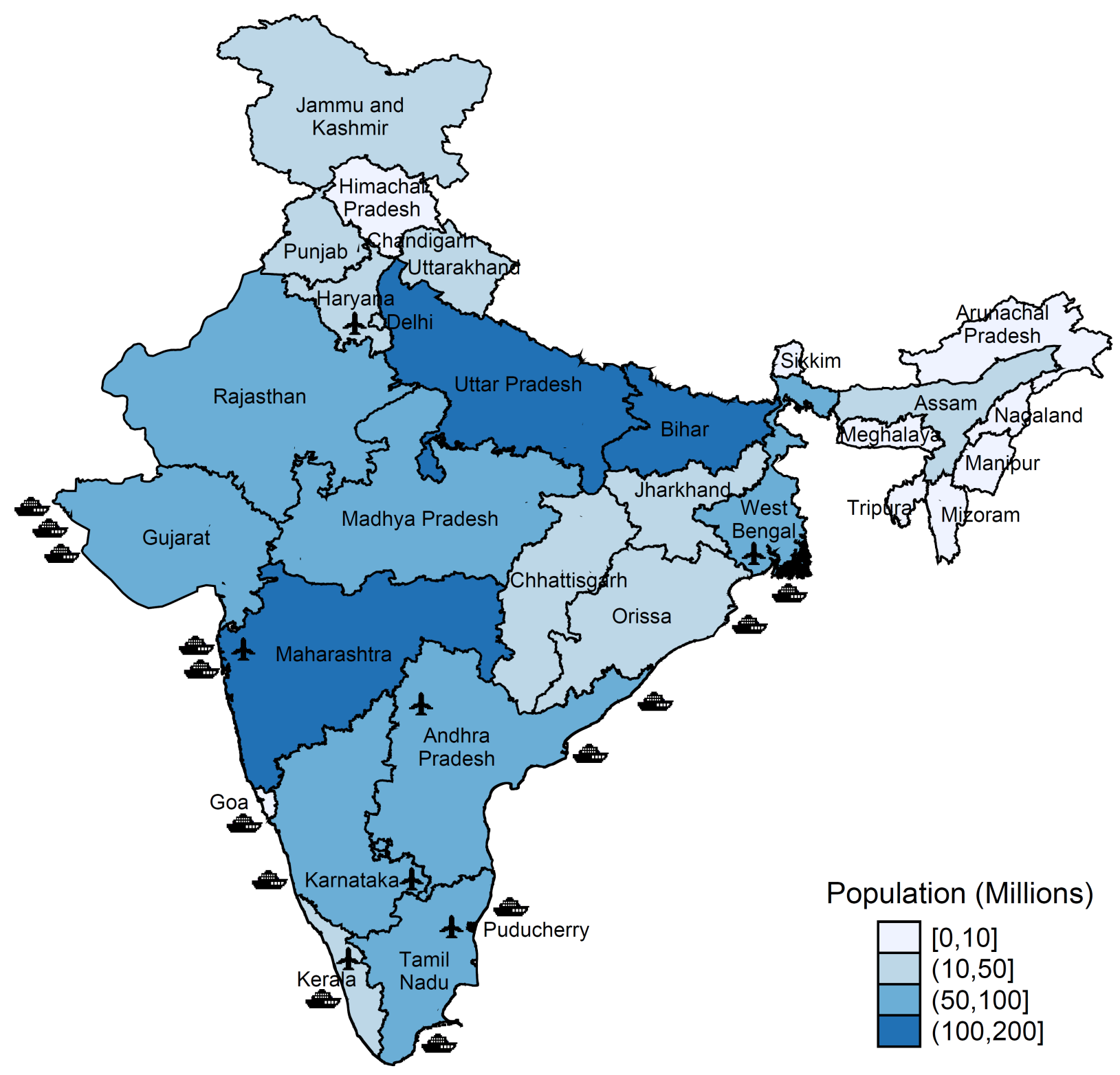

Figure 1: International Ports and Population in India

The top panel in Table 4 then breaks down the results for port and non-port states, where the port states are those states with a major international port as shown in Figure $1^{14}$ The first thing to note is that the observed trade patterns in the aggregate data are still present: both port and non-port states are trading little agriculture and are mostly trading manufacturing goods.

The second thing to note is that most of the international trade is driven by the port states, both for agriculture and manufacturing. For example, total manufacturing export openness is $34 \%$ for

\footnotetext{
${ }^{14}$ The 10 port states are Andhra Pradesh, Delhi, Goa, Gujarat, Karnataka, Kerala, Maharashtra, Orissa, Tamil Nadu, and West Bengal. The 20 non-port states are Arunachal Pradesh, Assam, Bihar, Chandigarh, Chattishgarh, Haryana, Himachal Pradesh, Jammu and Kashmir, Jharkhand, Madhya Pradesh, Manipur, Meghalaya, Mizoram, Nagaland, Puducherry, Punjab, Rajasthan, Tripura, Uttar Pradesh, and Uttarakhand.
} 
port states and only $7 \%$ for non-port states. These international trade openness results, thus, show there is substantial heterogeneity in how connected Indian states are internationally.

Table 4: International and Domestic Trade Openness

\begin{tabular}{|c|c|c|c|c|c|}
\hline & & \multicolumn{2}{|c|}{ Agriculture } & \multicolumn{2}{|c|}{ Manufacturing } \\
\hline & & Imports & Exports & Imports & Exports \\
\hline \multirow[t]{3}{*}{ International } & All States & $3 \%$ & $6 \%$ & $27 \%$ & $24 \%$ \\
\hline & Port States & $4 \%$ & $9 \%$ & $39 \%$ & $34 \%$ \\
\hline & Non-Port States & $1 \%$ & $3 \%$ & $6 \%$ & $7 \%$ \\
\hline \multirow[t]{3}{*}{ Domestic } & All States & $7 \%$ & $7 \%$ & $10 \%$ & $10 \%$ \\
\hline & Port States & $7 \%$ & $6 \%$ & $8 \%$ & $9 \%$ \\
\hline & Non-Port States & $6 \%$ & $7 \%$ & $13 \%$ & $12 \%$ \\
\hline
\end{tabular}

\subsubsection{Domestic Trade}

The bottom panel in Table 4 reports Indian states' domestic import and export openness. Similar to the international trade openness, the domestic trade openness for agriculture and manufacturing is defined as total domestic imports and exports divided by total sectoral production, respectively.

Total domestic trade openness in India amounts to $7 \%$ for agricultural and $10 \%$ for manufacturing goods ${ }^{15}$ In addition, these trade patterns are similar for port and non-port states, where the non-port states trade marginally more domestically. Combined with the results from the top panel in Table 4, port states trade more internationally than domestically, especially for manufacturing goods. For non-port states, the opposite is true; they trade both goods more domestically.

Furthermore, the overall magnitude of Indian domestic trade is relatively small compared to the

\footnotetext{
${ }^{15}$ The Internal trade data are symmetric, which implies the total export and import openness results for each good are also symmetric.
} 
United States. Using the Commodity Flow Survey data (CFS), Caliendo et al. (2014) find that total domestic trade as a fraction of GDP is $30 \%$ in the United States. ${ }^{16}$ In India, it is only $9 \%$, which indicates that Indian states trade relatively little with each other compared to the United States.

\section{Quantitative Analysis}

I now describe how the model maps to the data. The parameters taken from the trade literature are the elasticity of substitution and the trade elasticity for manufacturing $\left\{\theta_{m}, \sigma_{m}\right\}$. What I measure in the data are the elasticity of substitution and the trade elasticity for agriculture $\left\{\theta_{a}, \sigma_{a}\right\}$, the state population $L_{s}$ with $\beta_{s} \in[0,1]$ in the rural and $\left(1-\beta_{s}\right)$ in the urban regions, regional state wages $w_{s}^{r}$, and both rural-urban and cross-state trade barriers. In the context of the model, I compute four international trade barriers $\tau_{g, i m p}$ and $\tau_{g, \exp }$ with $g \in\{a, m\}$.

\subsection{Equilibrium Conditions}

States are indexed by $s=1 \ldots S, R o W$ where regions within a state are indexed by $r=R, U$ (rural and urban) and good types by $g=a, m$ (agriculture and manufacturing). Given parameters $\left\{\sigma_{a}, \sigma_{m}, \theta_{a}, \theta_{m}\right\}$, population data, $L_{s}$, of which the fraction $\beta_{s} \in[0,1]$ is located in the rural region, and state wages in the rural and urban regions, $\left\{w_{s}^{R}\right\}_{s=1 \ldots S, R o W}$ and $\left\{w_{s}^{U}\right\}_{s=1 \ldots S, R o W}$, I solve for productivity parameters , $\left\{T_{a, s}\right\}_{s=1 \ldots S, R o W}$ and $\left\{T_{m, s}\right\}_{s=1 \ldots S, R o W}$, such that labor markets clear, which is shown by equations (6) and (8).

Parameters As was shown in Section 2, the elasticities of substitution for agriculture and manufacturing govern the income elasticity of demand for manufacturing goods relative to agricultural goods, which decreases with income if $\sigma_{m}-\sigma_{a}>0$. I introduced these CRIE preferences to match agricultural and manufacturing consumption patterns. Hence, I fix $\sigma_{m}$ at 5 following Fieler (2011) and I calibrate $\sigma_{a}$ to match the share of total agricultural expenditures in India, which is $39 \%$.

\footnotetext{
${ }^{16}$ The CFS contains the total trade value of trade across all U.S. states, which amounted to 5.2 trillion USD in 2007. Caliendo et al. (2014) correct for international imports in the CFS and find that the CFS domestic shipment of goods is larger than the domestic consumption measure for all sectors, by a factor ranging from 1 to 1.4.
} 
The trade elasticity for manufacturing, $\theta_{m}$, is taken from Simonovska and Waugh (2014) ${ }^{17}$ and the trade elasticity for agriculture, $\theta_{a}$, is estimated following their method. The parameter values are given in Table 5. Note that the estimated trade elasticity for agriculture is comparable to international trade elasticities, which suggests that, even within India, gains from trade are substantial.

Table 5: Parameter Values

\begin{tabular}{l|l|l}
\hline \hline Parameter & Value & Explanation \\
\hline$\left\{\sigma_{A}, \sigma_{M}\right\}$ & $\{3.3,5\}$ & Elasticity of Substitution \\
$\left\{\theta_{a}, \theta_{m}\right\}$ & $\{5.6,5\}$ & Trade Elasticity \\
\hline \hline
\end{tabular}

State-based Indian Data The state-specific Indian data needed for the analysis are population, including the fraction in rural and urban regions, and region-specific wages.

The population data are obtained from the 2011 Indian census, which contains statistics on the population in each state and the fraction in rural and urban regions. Overall, $69 \%$ of the total population lives in rural regions ranging from $2 \%$ in Delhi to $90 \%$ in Himachal Pradesh.

Rural and urban wages are proxied by total production in the agricultural and manufacturing sectors divided by the population that lives in each region, respectively. Gross agricultural output in each state is taken from the state-based estimates of the value of output from agriculture and allied activities, which are published by MOSPI. The same state-based data for gross manufacturing output are not available. Therefore, I first obtain the total manufacturing output in India for 2011 from the United Nations Industrial Development Organization's (UNIDO) Industrial Statistics Database. Next, I use state-based GDP, which is obtained from the State Domestic Product series in 2011-12, also published by MOSPI, as a proxy to distribute output across states ${ }^{18}$ For the RoW, the output data are taken from UNIDO. ${ }^{19}$

\footnotetext{
${ }^{17}$ The trade elasticity of 5 for manufacturing is slightly higher than in Simonovska and Waugh (2014) because of the condition on $\sigma_{g}$ for a finite solution, i.e., $\left(\theta_{g}+1\right)>\sigma_{g}$.

${ }^{18}$ As a check I correlate total manufacturing output with total manufacturing employment, which can be obtained at the state level from MOSPI. I find a high positive correlation of 0.84, suggesting that state-based GDP is a good proxy for manufacturing output.

${ }^{19}$ Table A.1 in the online Appendix provides an overview of all the state-based data. One thing to note is that, on
} 


\subsection{Trade Barriers}

This section describes how internal barriers to trade in India, $D_{g, s l}^{r}$, are computed. I discipline both cross-state and rural-urban trade barriers by applying a no-arbitrage condition to disaggregated price data. The idea is that the price differential for any given good $g$ in any two different locations ( $s$ and $l$ ), is bounded from above by the bilateral trade cost, that is, $\frac{p_{s}\left(j_{g}\right)}{p_{l}\left(j_{g}\right)} \leq d_{s l}$. If this condition did not hold, there would be an arbitrage opportunity. Thus, an estimate of a trade barrier between any two locations is the maximum of relative prices over good variety $j_{g}$ :

$$
\log \hat{d}_{s l}=\max _{j_{g}} 2 \log \left\{p_{s}\left(j_{g}\right)-p_{l}\left(j_{g}\right)\right\}
$$

where $\max 2$ represents the second highest price difference to reduce measurement error.

I use disaggregated price data to discipline trade barriers across and within Indian states. The Data Portal of India publishes daily wholesale prices for agricultural good varieties across different markets in India (Mandi) ${ }^{20}$ It provides daily estimates for the minimum, maximum, and modal prices in a given market. The analysis in this paper is based on price data for 50 agricultural commodities across 1,831 markets in India during the fiscal year in India from April 2011 until March 2012 21

Using the price data, I compute a yearly region- and state-specific price for each commodity. I first average out the daily modal prices in each market to monthly prices, after which I drop the top 99th and bottom 1st percentile to reduce measurement error. Next, I average these prices to a yearly price for a specific commodity variety in a given market in India. Given that the model differentiates between a rural and urban region within a state, I map this feature into the data. I differentiate markets in each state as an urban or rural market, where an urban market is defined as being located in a city with a population of one million or more ${ }^{22}$ Finally, I compute an average urban and rural price for each commodity, which will be used to measure both cross-state and rural-urban trade barriers 23

average, wages (proxied by output per worker) in the urban regions are three times larger than in the rural regions, which is consistent with Restuccia et al. (2008).

${ }^{20}$ This dataset is generated through the AGMARKNET Portal, http://agmarknet.nic.in.

${ }^{21}$ The 50 agricultural commodities are listed in Table A.2 in the online Appendix.

${ }^{22}$ The Indian census of 2011 defines an urban agglomeration as a city with a population of one million or more.

${ }^{23}$ For two states, Arunachal Pradesh and Bihar, however, there is no price information. I use the average price information of the surrounding states. For Arunachal Pradesh, I use the average price data from Manipur, Meghalaya, 
Cross-State Trade Barriers As outlined previously, I will use a no-arbitrage condition to measure the cross-state trade barriers $\left\{d_{s l}\right\}_{s, l=1 \ldots S}$. Given that trade between states can occur only through the urban regions, I use the calculated average urban prices to measure the cross-state trade barriers. I compute the cross-state trade barriers for each state pair in India using the second highest price differential across each good variety. Hence, I calculate $(30 * 30-30)$ cross-state trade barriers, and Panel (a) in Figure 2 shows a histogram of the results. The median trade barrier is 2.52 , which implies a trade barrier of $150 \%$.

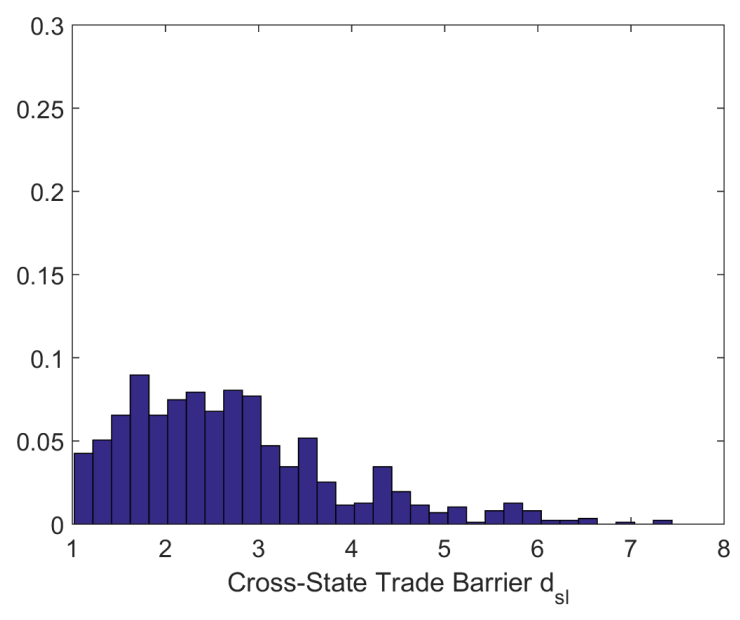

(a) India: Median $d_{s l}=2.52$

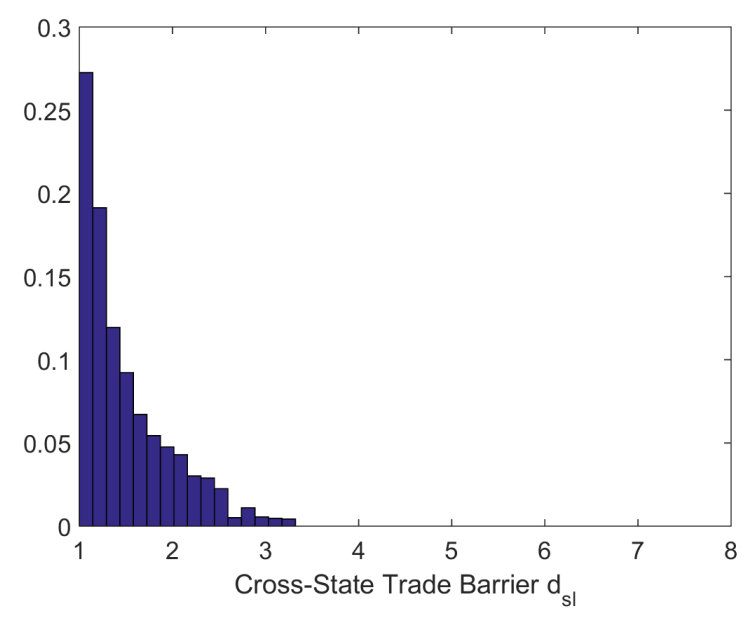

(b) U.S.: Median $d_{s l}=1.32$

Figure 2: Cross-State Trade Barriers

To assess the magnitude of these cross-state trade barriers in India, I compare them to the United States. The United States Department of Agriculture (USDA) collects prices on agricultural goods across 50 states and the District of Columbia. ${ }^{24}$ I apply the same no-arbitrage condition and measure cross-state trade barriers as the second highest price differential across each good variety. Panel (b) in Figure 2 shows a histogram of the computed cross-state trade barriers in the United States. I find a median trade cost of 1.32, which is around one-fifth of the Indian trade costs and around the same magnitude as other micro evidence has estimated. This is suggestive of relatively large trade frictions across Indian states, which corroborates the relatively small domestic trade flows presented in the bottom panel of Table 4.

Mizoram, Nagaland, and Tripura. For Bihar, I use the average price data from Uttar Pradesh and Assam.

${ }^{24}$ Table A. 3 in the online Appendix shows the 40 agricultural goods used in the United States. 
Rural-Urban Trade Barriers Next, I compute the rural-urban trade barriers, $\left\{\delta_{s}\right\}_{s=1 \ldots S}$, using the price variation across rural and urban markets within each state. I apply the same no-arbitrage condition given by equation (9) and calculate 30 rural-urban trade barriers. I find that the median rural-urban trade barrier is 1.48 and the $90-10$ percentile is 2.38 and 1.24 . These results imply that for the median state, prices in the urban area are 50\% more expensive than in the rural area and that the rural-urban trade barrier in certain states is almost as large as the median cross-state trade barrier 25

International Trade Barriers Finally, I estimate the international trade barriers from the international trade flows. Each Indian state is trading with the RoW, but not all states have access to an international port. Hence, states without an international port ship goods to and from the lowest cost port in order to trade internationally. Given the computed cross-state trade barriers from the price data, the cost to the lowest cost port is given by the minimum trade barrier from the specific non-port state to each of the port states. Then, I assume that once the goods are at the port, international export and import costs are the same across ports but not across goods.

I estimate four international trade barriers: agricultural and manufacturing import and export barriers denoted by $\tau_{a, i m p}, \tau_{m, i m p}, \tau_{a, \exp }$ and $\tau_{m, \exp }$, respectively. I calibrate those costs by matching the aggregate data moments given in the first row of Table 4. Let $X_{g, s R o W}$ be the state- and goodspecific import value from the RoW for good $g \in\{a, m\}$. Similarly, define $X_{g, R o W s}$ as the stateand good-specific export value from the state in India to the rest of the world for good $g \in\{a, m\}$. The four targeted moments are given by

$$
\left[\frac{\sum_{s} X_{a, s R o W}}{\sum_{s} X_{a, s}}, \frac{\sum_{s} X_{m, s R o W}}{\sum_{s} X_{m, s}}, \frac{\sum_{s} X_{a, R o W s}}{\sum_{s} X_{a, s}}, \frac{\sum_{s} X_{a, R o W s}}{\sum_{s} X_{m, s}}\right]
$$

where $\sum_{s} X_{g, s}$ is the total Indian sectoral production.

Table 6 shows the calibrated international trade barriers. Note that these are the border costs, that is, the trade barriers that the urban regions in port states face. Section 5 compares their mag-

\footnotetext{
${ }^{25}$ I find the computed rural-urban trade barriers are positively correlated with the density of the infrastructure network in each state. More specifically, I find a correlation coefficient of 0.58 between the estimated rural-urban trade barriers and the median distance from each market to the nearest railway.
} 
nitude to that of the internal trade barriers.

These calibrated border trade barriers are consistent with earlier work on international trade barriers for developing countries. First, the export barrier for manufacturing is higher than the import barrier. This is consistent with Waugh (2010). Second, the import barrier for agriculture is about three times larger than for manufacturing, which is line with Tombe (2015).

Table 6: International Border Trade Barriers

\begin{tabular}{c|cc}
\hline \hline & Agriculture & Manufacturing \\
\hline Import & $\tau_{a, i m p}=2.57$ & $\tau_{m, i m p}=1.49$ \\
Export & $\tau_{a, \exp }=2.14$ & $\tau_{m, \exp }=2.92$ \\
\hline \hline
\end{tabular}

\subsection{Fit Model}

Given the model calibration, I test how well the model fits the international and domestic trade data.

International Trade One of the model's innovations is to allow for state heterogeneity in terms of access to an international port. This was motivated by the international trade openness results in the top panel of Table 4, which show that port states trade substantially more internationally than non-port states. To test the fit of the model regarding international trade, I perform two analyses. The first tests how well the model captures the non-targeted heterogeneity in trade openness across port and non-port states. The second recalibrates the border trade barriers for the same trade model with the exception that all states have an international port to quantitatively assess the importance of differential port access 26

Table 7 shows the results for agricultural and manufacturing trade. Column one for each good shows the data: the export and import openness as reported in the top panel in Table 4 . Column two shows the results for the "new model" in this paper with heterogeneous international port

\footnotetext{
${ }^{26}$ Section A.5 in the online Appendix provides more detail on the calibration and the international trade barriers.
} 
access. Column three shows the export and import openness results for the "old model" without differentiating port access.

First, I compare columns one and two for each good to evaluate the fit of the model. The model performs very well in terms of both capturing the non-targeted heterogeneity in international trade openness across port and non-port states and matching the shares. For instance, for agriculture, the model captures that port states trade substantially more than non-port states. Furthermore, the model matches the import and trade openness almost perfectly: port states import $4 \%$ and export $10 \%$ of the total production, whereas for non-port states it is only $0.6 \%$ and $2 \%$. With regard to manufacturing, the model can account for the large difference in import and export trade openness of port states compared to non-port states. Nevertheless, it slightly underestimates international trade for port states ( 2 percentage points) and overestimates trade for non-port states ( 4.5 percentage points).

Table 7: Non-Targeted Model Moments

\begin{tabular}{|c|c|c|c|c|c|c|c|}
\hline & & \multicolumn{3}{|c|}{ Agriculture } & \multicolumn{3}{|c|}{ Manufacturing } \\
\hline & & Data & New & Old & Data & New & Old \\
\hline & & & Model & Model & & Model & Model \\
\hline \multirow{2}{*}{$\begin{array}{l}\text { Port } \\
\text { States }\end{array}$} & Imports & $4 \%$ & $4 \%$ & $3 \%$ & $39 \%$ & $36 \%$ & $23 \%$ \\
\hline & Exports & $9 \%$ & $10 \%$ & $6 \%$ & $34 \%$ & $33 \%$ & $21 \%$ \\
\hline \multirow{2}{*}{$\begin{array}{l}\text { Non-Port } \\
\text { States }\end{array}$} & Imports & $0.7 \%$ & $0.6 \%$ & $2 \%$ & $6 \%$ & $11 \%$ & $32 \%$ \\
\hline & Exports & $3 \%$ & $2 \%$ & $6 \%$ & $6 \%$ & $10 \%$ & $29 \%$ \\
\hline
\end{tabular}

Second, I compare columns one and three for each good. As mentioned before, column three shows the results for a recalibrated model in which all states have access to an international port. Table 7 shows that this "old model" does significantly worse than the "new model" in capturing the heterogeneity and magnitude in international trade for port versus non-port states. For agriculture, 
non-port states trade as much as port states, and for manufacturing, they trade even more than port states. Both of these implications are counterfactual.

Thus, taking into account differential port access is quantitatively important to explain statebased international trading patterns.

Domestic Trade Next, I test how well the computed domestic trade barriers predict domestic trade flows in India for agricultural and manufacturing goods. Figure 3 shows the model- versus the data-weighted trade flows $z_{g, s l}=\frac{X_{g, s l}}{X_{g, s} X_{g, l}}$ for both agriculture and manufacturing. The model predicts domestic trade flows well, especially for agriculture. The correlations are reasonably high and significant, with a correlation of 0.67 for agricultural and 0.55 for manufacturing trade. Nevertheless, the model overestimates domestic trade in manufacturing goods.

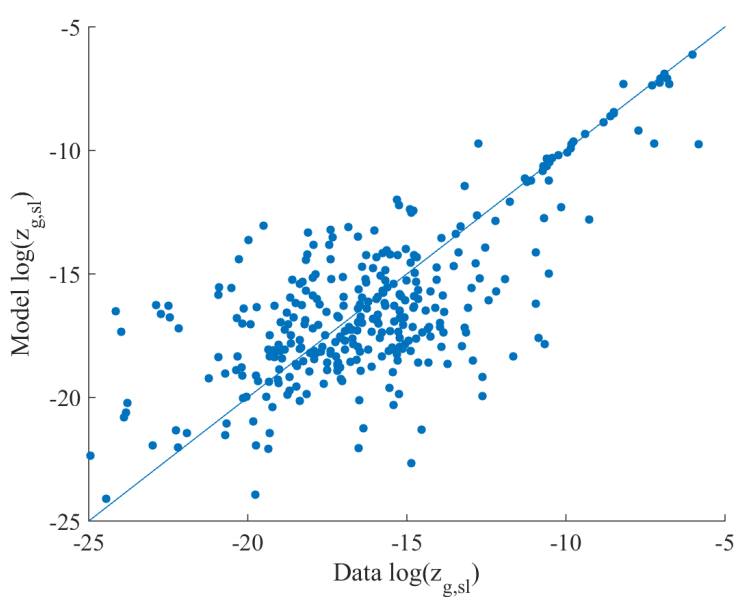

(a) Agriculture: corr $=0.67$

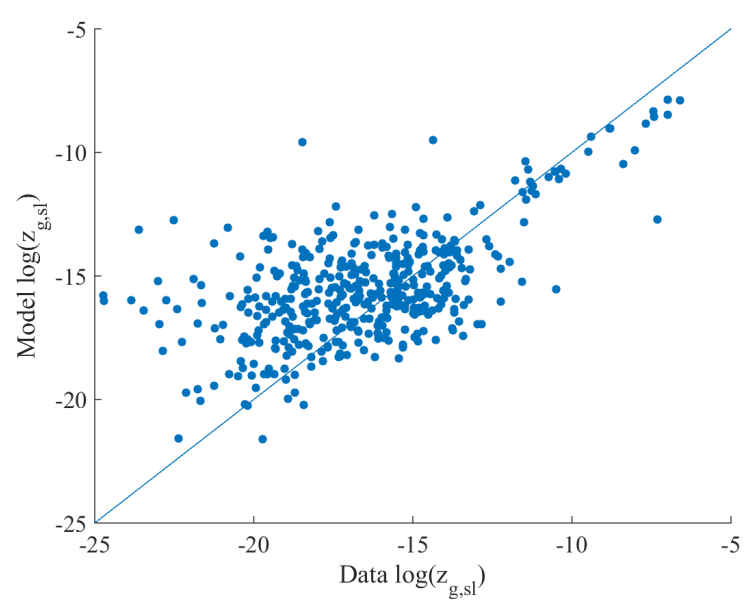

(b) Manufacturing: corr $=0.55$

Figure 3: Indian Domestic Trade

\section{Results}

First, I compare the magnitude of internal versus external trade barriers and their heterogeneity across port and non-port states. Second, I perform several counterfactual experiments to assess the trade and welfare effects of internal versus external integration. Finally, I study the nature of internal trade barriers. 


\subsection{Size of Internal versus External Trade Barriers}

Table 8 presents the total trade barriers Indian states face to import and export internationally ${ }^{27}$ These are a combination of the border trade barriers presented in Table 6 , together with the internal trade barriers, which consist of a cross-state trade barrier for non-port states, and a rural-urban trade barrier for all states. Table 8 contains two blocks, one for imports and the other for exports, each consisting of four columns. The first column in each block reports the median populationweighted trade barrier faced by all states. The second column shows the internal trade barrier as a fraction of the total trade barrier. Columns three and four show the breakdown of the internal trade barrier into a cross-state and a rural-urban trade barrier, respectively. These percentages sum up to the total internal trade barrier. In addition, all trade barriers are broken down for agricultural and manufacturing goods and for port and non-port states.

A first result from Table 8 is that internal trade barriers account for a substantial fraction of the total trade barriers: $44 \%$ of total international import barriers and $29 \%$ of total international export barriers. In other words, for international imports, shipping from the RoW to the ports of India accounts for $56 \%$ of the total barrier, whereas shipping from the ports in India to the destination accounts for $44 \%$ of the total barrier. For exports the fraction of internal barriers is slightly less, $29 \%$, due to the relative high border export costs I calibrated in Table 6 .

The breakdown of import barriers by good shows that shipping agricultural goods from the Indian ports to the final destination in India represents one-third (34\%) of the total import trade barrier. For manufacturing imports, it represents almost two-thirds (62\%) of the total import barrier. The reason is that the border import barrier is smaller for manufacturing.

A second result from Table 8 is that the non-port states face the highest total trade barriers, that is, around three times higher than the port states, for both international imports and exports. This is mainly driven by the additional cross-state barrier non-port states incur when trading internationally. The fraction of internal barriers for non-port states is on average $62 \%$ of total import and $46 \%$ of total export barriers. This implies that moving goods from the port to the destination in India is substantially more expensive than moving goods from the RoW to the Indian port.

\footnotetext{
${ }^{27}$ Tables A.4, A.5, A.6, and A.7 in the online Appendix show the results for each state.
} 
Table 8: Fraction and Breakdown Internal Trade Barriers

\begin{tabular}{|c|c|c|c|c|c|c|c|c|}
\hline & \multicolumn{4}{|c|}{ International Imports } & \multicolumn{4}{|c|}{ International Exports } \\
\hline & $\begin{array}{l}\text { Total } \\
\text { Barrier }\end{array}$ & Internal & $\begin{array}{l}\text { Cross- } \\
\text { State }\end{array}$ & $\begin{array}{l}\text { Rural- } \\
\text { Urban }\end{array}$ & $\begin{array}{l}\text { Total } \\
\text { Barrier }\end{array}$ & Internal & $\begin{array}{l}\text { Cross- } \\
\text { State }\end{array}$ & $\begin{array}{l}\text { Rural- } \\
\text { Urban }\end{array}$ \\
\hline \multicolumn{9}{|l|}{ All States } \\
\hline Average & 3.65 & $44 \%$ & $19 \%$ & $25 \%$ & 4.15 & $29 \%$ & $13 \%$ & $16 \%$ \\
\hline Agriculture & 4.62 & $34 \%$ & $15 \%$ & $19 \%$ & 4.32 & $47 \%$ & $20 \%$ & $27 \%$ \\
\hline Manufacturing & 2.67 & $62 \%$ & $27 \%$ & $35 \%$ & 4.00 & $16 \%$ & $7 \%$ & $9 \%$ \\
\hline \multicolumn{9}{|l|}{ Port States } \\
\hline Average & 2.42 & $16 \%$ & $0 \%$ & $16 \%$ & 2.90 & $9 \%$ & $0 \%$ & $9 \%$ \\
\hline Agriculture & 3.07 & $11 \%$ & $0 \%$ & $11 \%$ & 2.88 & $23 \%$ & $0 \%$ & $23 \%$ \\
\hline Manufacturing & 1.77 & $29 \%$ & $0 \%$ & $29 \%$ & 2.92 & $0 \%$ & $0 \%$ & $0 \%$ \\
\hline \multicolumn{9}{|l|}{ Non-Port States } \\
\hline Average & 5.48 & $62 \%$ & $32 \%$ & $30 \%$ & 5.81 & $46 \%$ & $24 \%$ & $22 \%$ \\
\hline Agriculture & 6.95 & $52 \%$ & $27 \%$ & $25 \%$ & 6.62 & $65 \%$ & $34 \%$ & $31 \%$ \\
\hline Manufacturing & 4.02 & $78 \%$ & $41 \%$ & $37 \%$ & 5.00 & $27 \%$ & $14 \%$ & $13 \%$ \\
\hline
\end{tabular}

Figure 4 shows internal barriers as a fraction of the total trade barriers for all states. This is an average across import and export barriers. As mentioned before, there is large heterogeneity in the fraction of internal trade barriers: the $90-10$ percentile is $70-13 \%$. Most of this heterogeneity is driven by port versus non-port states, where internal barriers account for $17 \%$ and $51 \%$, respectively. Furthermore, as states are more removed from a major port, the fraction of internal trade barriers increase, going up to $73 \%$ of the total trade barrier in Himachal Pradesh. 


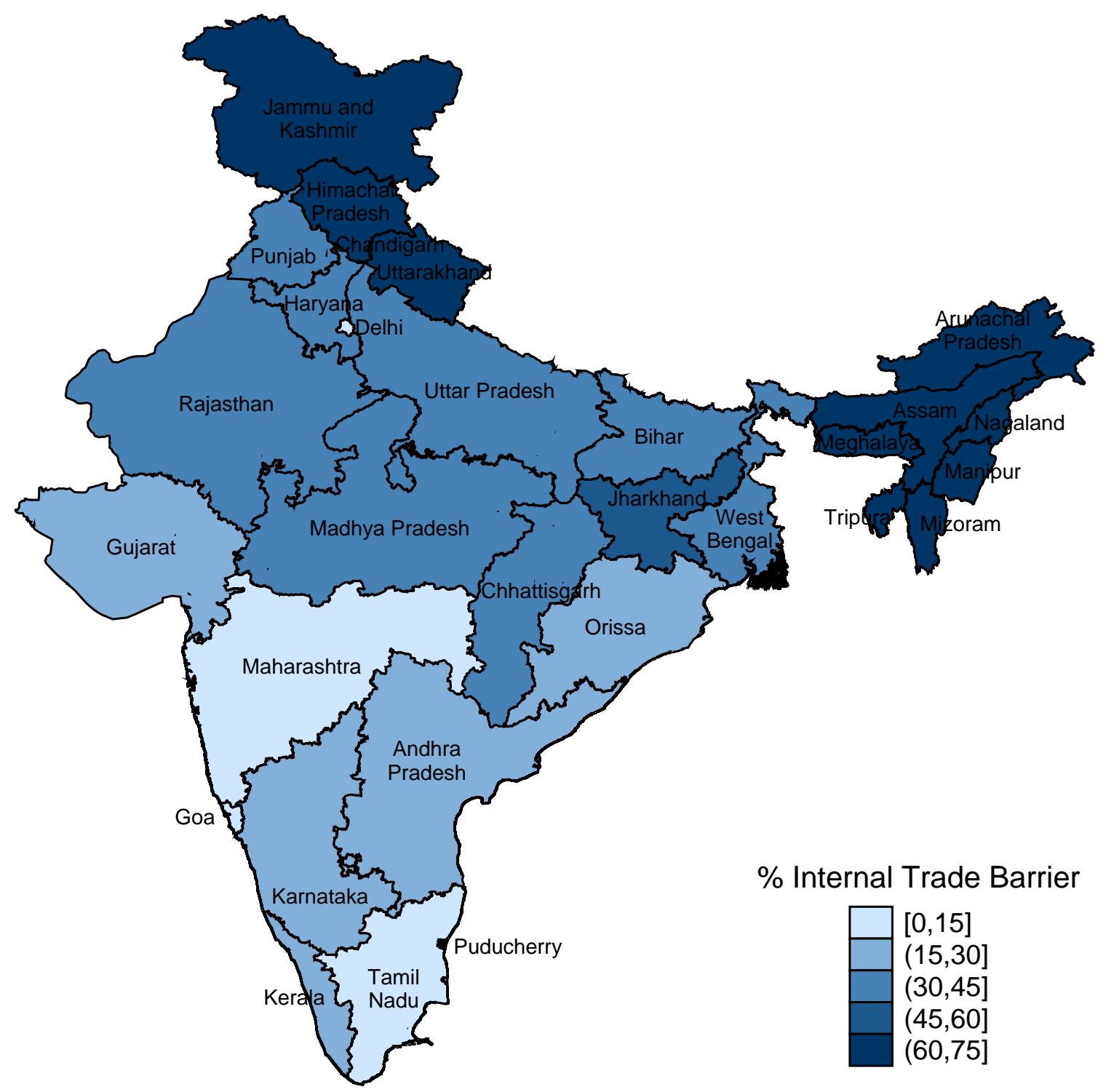

Figure 4: Fraction of Internal Trade Barriers

A final result from Table 8 is the breakdown of internal trade barriers into cross-state and ruralurban trade barriers. On average, the rural-urban trade barrier represents a higher fraction of the total compared to the cross-state trade barrier: $25 \%$ versus $19 \%$ for imports and $16 \%$ versus $13 \%$ for exports. This is driven by the fact that half of the population lives in port states that do not face any additional cross-state trade barrier when trading internationally. This is clear from the port results, which shows that port states face no cross-state trade barriers. Nevertheless, even for the non-port states, the rural-urban trade barriers are almost as high as the cross-state trade barriers, which suggests that rural-urban trade barriers also impose a substantial barrier to international trade. 


\subsection{Counterfactuals}

With the calibrated model, I now analyze counterfactual experiments. The procedure is as follows: given the same state population, $L_{s}$; rural population shares, $\beta_{s}$; parameter values $\sigma_{a}, \sigma_{m}, \theta_{a}, \theta_{m}$; and the productivity vectors $T_{a, s}$ and $T_{m, s}$, I change specific trade barriers. Then, I recalculate wages in the urban and rural regions of each state such that labor markets clear given by equations (6) and (8). To study the impact of reducing trade barriers, I consider two measures. The first is the change in overall international imports as a fraction of production ${ }^{28}$ The second is the change in welfare. Welfare is measured as a compensating variation: by how much do wages in each region need to change in order to receive the same utility in the baseline as in the counterfactual? Utility can be written as follows:29

$$
U_{s}=\lambda_{s}^{r}\left[\left(\frac{\sigma_{a}}{\sigma_{a}-1}\right) x_{s, a}^{r}+\left(\frac{\sigma_{m}}{\sigma_{m}-1}\right) x_{s, m}^{r}\right],
$$

where $x_{s, g}^{r}=\int_{0}^{1} q_{s}^{r}\left(j_{g}\right) p_{s}^{r}\left(j_{g}\right) d j_{g}$ is defined as the state-region-specific expenditure on good variety $j_{g}$. To aggregate each region- and state-level compensation variation into an aggregate welfare measure, I weigh them by region- and state-level population.

First, I study two counterfactuals aimed at international integration, after which I examine three counterfactuals aimed at internal integration 30

\subsubsection{Removing International Import Barriers}

The first policy experiment is the removal of international import barriers, that is, $\tau_{a, i m p}=\tau_{m, i m p}=$ 1. The impact on international imports is shown in column (1) of the top panel in Table 9. It first presents the results for all states and breaks down the results by port and non-port states. After a removal of international import barriers international trade would increase substantially;

\footnotetext{
${ }^{28} \mathrm{As}$ trade is balanced, the impact on international exports is similar. There are some differences in exports and imports across goods for port states and non-port states, however, and these results are reported in Table A.8 in the online Appendix.

${ }^{29}$ See Section A.7 in the online Appendix.

${ }^{30}$ Note that I only study the potential benefits from international versus internal integration, and do not take into account the costs. One might be concerned that building better infrastructure in India is more costly than reducing international import tariffs, for instance. Nevertheless, Section 5.3 provides evidence that internal trade barriers consist of physical and policy barriers, which implies that there is scope for removing 'lower cost' policy barriers in India.
} 
whereas India currently imports $17 \%$ of its total production, it would now import $37 \%$. However, the international trade breakdown across port and non-port states shows that the total fraction of imported goods is still largest for the port states; they would import $50 \%$ of total production as opposed to $18 \%$ in the non-port states. The reason for these different impacts on international trade is that non-port states still face the additional cross-state trade barrier to move goods to and from the international port. As these trade barriers make up more than half of the total trade barriers, removing international import barriers does not increase imports to the level of the port-states.

Table 9: International Trade and Welfare Effects

\begin{tabular}{|c|c|c|c|c|c|c|}
\hline & Baseline & $\begin{array}{c}\text { Import } \\
\text { (1) }\end{array}$ & $\begin{array}{l}\text { Cross-State } \\
\text { to Port } \\
\text { (2) }\end{array}$ & $\begin{array}{c}\text { Cross- } \\
\text { State } \\
(3)\end{array}$ & $\begin{array}{c}\text { Rural- } \\
\text { Urban } \\
\text { (4) }\end{array}$ & $\begin{array}{l}\text { Cross-State } \\
\text { to U.S. } \\
\text { (5) }\end{array}$ \\
\hline \multicolumn{7}{|c|}{ International Imports } \\
\hline Aggregate & $17 \%$ & $37 \%$ & $26 \%$ & $11 \%$ & $21 \%$ & $14 \%$ \\
\hline Port States & $24 \%$ & $50 \%$ & $24 \%$ & $11 \%$ & $29 \%$ & $16 \%$ \\
\hline Non-Port States & $6 \%$ & $18 \%$ & $28 \%$ & $10 \%$ & $9 \%$ & $11 \%$ \\
\hline \multicolumn{7}{|l|}{ Welfare } \\
\hline Aggregate & . & $7 \%$ & $2 \%$ & $30 \%$ & $18 \%$ & $13 \%$ \\
\hline Port States & . & $12 \%$ & $-0 \%$ & $29 \%$ & $19 \%$ & $12 \%$ \\
\hline Non-Port States & . & $2 \%$ & $4 \%$ & $31 \%$ & $17 \%$ & $14 \%$ \\
\hline
\end{tabular}

These trade results are also reflected in the welfare impacts presented in the bottom panel of Table 9. Column two shows that after removing import barriers, total welfare increases by $7 \%$. Separating the impact across port and non-port states shows that welfare gains are concentrated in the port states. They experience welfare gains of $12 \%$, whereas the non-port states only gain $2 \%$. 
The aggregate welfare gains from removing international import barriers primarily stem from increased international imports, which has two effects: prices decrease because of lower cost imports, but wages also decrease due to higher international competition. In the aggregate, I find that the price effect outweighs the wage effect. However, because the effect on international imports is lower for non-port states, the price effect is dampened. Thus, their welfare gains are lower compared to the port states.

Overall, this shows that policies focused on reducing international import barriers have very heterogeneous trade and welfare effects depending on international port access. In fact, Table A.10 of the online Appendix shows that the previously outlined model (Table 7), without differential international port access across Indian states, would overestimate the gains from removing international import barriers by 6 percentage points, as it would overestimate the trade and welfare effects for non-port states.

\subsubsection{Building International Ports in All States}

The previous section showed that transporting goods to and from an international port for nonport states is quantitatively important for the welfare gains from international trade liberalization. Therefore, the second counterfactual is to estimate the impact of building an international port in all non-port states, thereby increasing market access to the RoW. In the model, only the cross-state trade barriers to and from the international port for non-port states are removed, while keeping the cross-state trade barriers within India constant.

The trade results are shown in column (2) in the top panel of Table 9. Aggregate international imports increased to $26 \%$ from $17 \%$, but not by as much as removing import barriers (37\%). Distinguishing international imports to the port states from those to the non-port states, the aggregate increase is coming from the latter: international imports as a fraction of production increase from $6 \%$ to $28 \%$. The intuition is that the cross-state trade barriers to move goods to and from international ports are on average larger than the international trade barriers. By removing them, international imports increase by more for non-port states compared to when import barriers are completely removed.

The welfare effects in column (2) in the bottom panel show that aggregate welfare increases by 
$2 \%$. This implies that removing international import barriers increases welfare more than removing the barriers to access international ports. This is primarily driven by the small welfare losses experienced in the port states. They are marginally worse off due to increased port competition, which drives down wages more than prices, as international imports only slightly increase. Nonport states, however, benefit more from having direct access to an international port than from removing international import barriers: $4 \%$ compared to $2 \%$. This result suggests that removing the costs of moving goods from and to the ports are quantitatively important and should be considered when designing international trade policies.

This concludes the examination of the two counterfactuals aimed at international integration. I will now consider three counterfactuals aimed at domestic integration.

\subsubsection{Removing Cross-State Trade Barriers}

The first counterfactual aimed at internal integration is the removal of cross-state trade barriers, that is, $d_{s, l}=1 \forall s, l=1 \ldots S$. The impact on international imports is shown in column (3) in the top panel of Table 9. It shows that aggregate international imports would decrease 5 percentage points to $11 \%$ of total production. This aggregate decline is driven by port states as they reduce international imports and increase imports from other Indian states. For non-port states, international imports actually increase from $6 \%$ in the baseline to $10 \%$. This is because removing cross-state barriers not only makes trade with other states in India cheaper, but it also decreases the cost of trading internationally as it becomes cheaper to move goods to and from the nearest port.

Now consider the welfare effects in column (3) in the bottom panel of Table 9. First, the total welfare gains are substantial: $30 \%$ compared to $7 \%$ when removing import barriers, which suggests that India has more to gain from becoming more integrated internally than removing import barriers.

Second, both port and non-port states experience welfare gains around the same magnitude: 29 and $31 \%$, respectively. Thus, the welfare gains are more equally distributed across states, which is in contrast to when import barriers are removed. The reason is that when international import barriers are removed, the non-port states do not experience large welfare gains compared to port states because they still incur large internal barriers to trade to and from the international 
port. Thus, there are big heterogeneous welfare impacts, with the largest gains concentrated in the port states. When internal trade barriers are removed, however, all states benefit from cheaper Indian goods. In addition, non-port states experience an additional welfare gain from cheaper international goods. To summarize, removing cross-state trade barriers in India generates larger and more equally distributed welfare gains than removing import barriers.

\subsubsection{Removing Rural-Urban Trade Barriers}

The second counterfactual aimed at internal integration is the removal of rural-urban trade barriers, that is, $\delta_{s}=1 \forall s=1 \ldots S$. Column (4) in the top panel of Table 9 shows that aggregate international imports would increase 4 percentage points to $21 \%$ of total production. Both port and non-port states import more from the RoW, with the overall level still being higher in port states: $29 \%$ compared to $9 \%$ for non-port states. An interesting thing to note is that international trade is affected differently depending on the type of internal integration in India. When cross-state trade barriers are removed, international trade decreases because port states increase internal trade. Alternately, when rural-urban trade barriers are removed, international trade increases as port states trade more internationally because the barrier to international trade has decreased. Overall, this suggests that rural-urban trade barriers impose a significant barrier to international trade for all states.

Column (4) in the bottom panel of Table 9 shows the respective welfare impacts. Aggregate welfare gains are $18 \%$, which is larger than any aggregate welfare impact from policies aimed at international integration. This suggests that there are large potential welfare gains from connecting rural and urban regions. In addition, the gains are, again, more equally distributed across states compared to removing international import barriers. Nevertheless, if we compare the two types of internal integration in India, the results indicate that India has more to gain from connecting states in India by decreasing cross-state trade barriers.

\subsubsection{Reducing Cross-State Trade Barriers to U.S. Level}

The previous four counterfactuals have shown the welfare gains of removing barriers internationally and domestically. As these policies are extreme, I perform a final, more 'realistic' counterfac- 
tual experiment in which I reduce cross-state trade barriers in India to those observed in the United States. Figure 2 showed that cross-state trade barriers in India are about five times larger than those in the U.S. Hence, I divide all cross-state trade barriers in India, $d_{s l}$, by the same fraction such that the median trade barrier in the counterfactual Indian data is the same as in the United States (1.32).

Column (5) in Table 9 shows the effects on international trade and welfare. The same intuition holds as in the counterfactual when cross-state barriers are removed. The primary result from this final counterfactual is that reducing cross-state trade barriers in India to the level of those in the United States leads to welfare gains of $13 \%$, which is still larger than the welfare gains from removing international import barriers: $7 \%$. This implies that India has more to gain from becoming more integrated internally than from removing international import barriers.

Figure 5 graphically presents the welfare results across Indian states. Panel (a) presents the state-wise welfare changes when international import barriers are removed. A removal of them mostly benefits the port states, with welfare gains rising to $38 \%$ in Delhi. The non-port states, however, experience smaller welfare gains up to 5\%, and some even experience welfare losses.

Panel (b) presents the state-based welfare changes when internal barriers in India are reduced to the U.S. level. In this scenario, all states experience welfare gains and they are as large or larger than those in Panel (a). Furthermore, the states that benefit most are the non-port states located in the northern and north eastern regions of India. Thus, India has more to gain from becoming more integrated domestically and the welfare gains are more equally distributed across states.

The intuition is that large barriers to trade within India make port states trade more with the rest of the world because they have access to cheaper international goods. Non-port states, on the other hand, trade more within India as international trade is expensive due to high internal trade barriers. When internal trade barriers are reduced, trade across all states in India increases. This increases welfare for port states as they benefit from cheaper Indian products. Non-port states also benefit from cheaper Indian products due to increased cross-state trade, but also from lower cost international trade due to smaller trade barriers to and from international ports. 


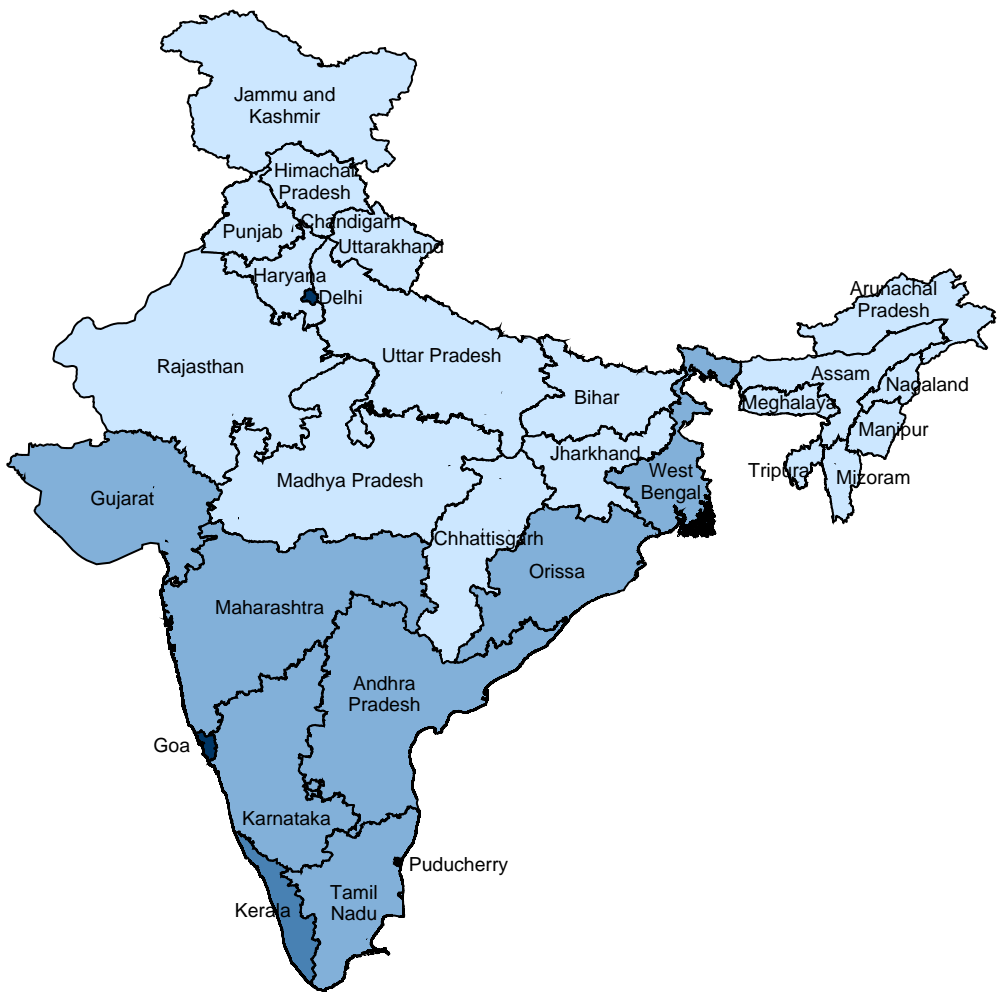

(a) Remove International Import Barriers

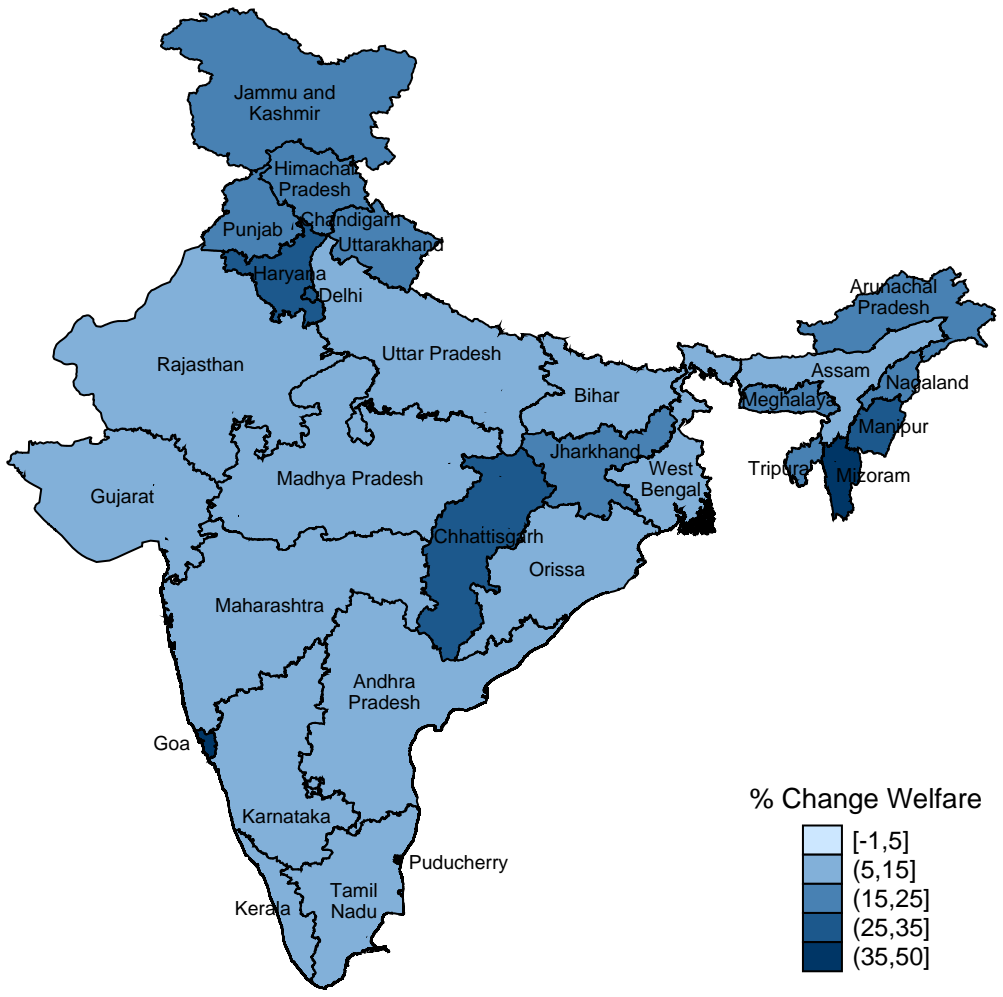

(b) Reduce Cross-state Trade Barriers to U.S.

Figure 5: Welfare Comparison External versus Internal Integration 


\subsection{The Nature of Cross-State Trade Barriers}

The previous section showed that India has more to gain from reducing cross-state trade barriers, where cross-state barriers were computed from cross-state price dispersion. The advantage of using price dispersion to discipline trade barriers instead of direct measures such as distance is that it encompasses more than just infrastructure barriers. Nevertheless, to design policies focused on domestic integration, it is important to decompose these cross-state trade barriers. Therefore, this section provides more insight into the nature of the estimated cross-state trade barriers by regressing them on measures of infrastructure as well as policy and culture. I run the following regression:

$$
\log \left(d_{s l}\right)=\alpha+\beta X_{s l}+\varepsilon_{s l}
$$

where $d_{s l}$ is the cross-state trade barrier between states $s$ and $l$ and $X_{s l}$ is the set of explanatory variables.

To proxy the infrastructural barrier, I use two measures: the distance between state capitals and the number of state borders between states. Because these two measures are highly correlated, I run the main specification given by equation (11) separately in Panels I and II of Table 10 .

For the policy barriers, I use measures of corruption, the arduousness of the tax administration, and tax rates themselves. To measure these variables, I use the World Bank Enterprise Survey data for India in 2014, which contains almost 10,000 firms spread across all Indian states except the union territories Puducherry and Chandigarh. The survey asks to what degree tax rates, tax administration, and corruption are an obstacle to the current operations of the establishment. The responses range from "No Obstacle" to "Very Severe Obstacle". I use these responses to provide a comparable measure of these factors across states. I convert these qualitative measures to dummy variables by first taking the fraction of firms that answered either "Major Obstacle" or "Very Severe Obstacle" in response to the three variables of interest. I then create a dummy variable that is equal to one if the fraction of firms is above the 90th percentile in either the origin or destination state, and zero otherwise ${ }^{31}$ As a final non-infrastructural barrier, I include a cultural barrier to trade,

\footnotetext{
${ }^{31}$ I arbitrarily choose the 90th percentile to capture the effect of those states where either of the three variables is a major issue.
} 
which indicates whether states share the same main language.

Panel I of Table 10 shows the results when infrastructure is proxied by distance. First, I consider the infrastructural barrier. Column (1) presents the results for distance as the only explanatory variable in equation (11). It shows that if the distance between two states increases by $1 \%$, the trade barrier increases by $0.19 \%$, and this coefficient is highly significant. In addition, the adjusted $R^{2}$ is 0.12 , which implies that distance in itself can explain $12 \%$ of the variation in cross-state trade barriers.

Second, I consider the impact of the three policy barriers in columns (2), (3), and (4). Column (2) shows that trade barrier between two states increases by $17 \%$ if corruption is high in either state, and this coefficient is also highly significant. The adjusted $R^{2}$ rises from 0.12 to 0.18 , which suggests that corruption plays an important role in the size of trade barriers. In column (3), I include a dummy that indicates a burdensome tax administration. The coefficient is again highly significant and economically important. It shows that trade barriers would increase by $23 \%$ if either the importing or exporting state faces a difficult tax administration. The adjusted $R^{2}$ also increased from 0.18 to 0.24 . Column (4) includes the final policy barrier: the tax rate. The significant coefficient indicates that states with higher tax rates face an additional trade barrier of $12 \%$.

Finally, I include a dummy variable that indicates whether the main language is the same across states. There are 14 different main languages across the 27 states and three union territories in the analysis. The results are presented in column (4). They show that if two states share their main language, their cross-state trade barrier decreases by $17 \%$. This result highlights that even cultural barriers in India are economically important.

Panel II of Table 10 shows the same results as Panel I, but with the second proxy for infrastructure: the number of state borders between any two states in India. Column (1) shows that the coefficient is positive and highly significant. An interesting thing to note is that the adjusted $R^{2}$ is higher compared to that when infrastructure was proxied by distance: 0.16 compared to 0.12 , respectively. This implies that the actual number of state borders when trading across states is more informative about the cross-state trade barriers than distance. This is exactly in line with the earlier result which indicated that the largest welfare gains from internal integration are associated with connecting states in India. 
Table 10: Nature of Cross-State Trade Barriers

\begin{tabular}{|c|c|c|c|c|c|}
\hline & (1) & (2) & (3) & (4) & (5) \\
\hline \multicolumn{6}{|l|}{ Panel I } \\
\hline $\begin{array}{l}\log (\text { Distance }) \\
\text { s.e. } \\
\text { High Corruption } \\
\text { s.e. } \\
\text { High Tax Administration } \\
\text { s.e. } \\
\text { High Tax Rates } \\
\text { s.e. } \\
\text { Language } \\
\text { s.e. } \\
\text { Constant } \\
\text { s.e. }\end{array}$ & $\begin{array}{c}0.19 * * * \\
(0.02)\end{array}$ & $\begin{array}{c}0.22 * * * \\
(0.02) \\
0.17 * * * \\
(0.03)\end{array}$ & $\begin{array}{c}0.22 * * * \\
(0.02) \\
0.18^{* * *} \\
(0.03) \\
0.23 * * * \\
(0.03)\end{array}$ & $\begin{array}{c}0.22 * * * \\
(0.02) \\
0.19^{* * * *} \\
(0.03) \\
0.24 * * * \\
(0.03) \\
0.12^{* * * *} \\
(0.03)\end{array}$ & $\begin{array}{c}0.18^{* * *} \\
(0.02) \\
0.22^{* * *} \\
(0.03) \\
0.25^{* * *} \\
(0.03) \\
0.12^{* * *} \\
(0.03) \\
-0.17^{* * *} \\
(0.03) \\
-0.32^{* *} \\
(0.14)\end{array}$ \\
\hline $\begin{array}{l}\text { Observations } \\
\text { Adjusted } R^{2}\end{array}$ & $\begin{array}{l}756 \\
0.12 \\
\end{array}$ & $\begin{array}{l}756 \\
0.18 \\
\end{array}$ & $\begin{array}{l}756 \\
0.24 \\
\end{array}$ & $\begin{array}{l}756 \\
0.25 \\
\end{array}$ & $\begin{array}{l}756 \\
0.28 \\
\end{array}$ \\
\hline \multicolumn{6}{|l|}{ Panel II } \\
\hline $\begin{array}{l}\text { \# of Borders } \\
\text { s.e. } \\
\text { High Corruption } \\
\text { s.e. } \\
\text { High Tax Administration } \\
\text { s.e. } \\
\text { High Tax Rates } \\
\text { s.e. } \\
\text { Language } \\
\text { s.e. } \\
\text { Constant } \\
\text { s.e. }\end{array}$ & $\begin{array}{c}0.09 * * * \\
(0.01)\end{array}$ & $\begin{array}{c}0.12 * * * \\
(0.01) \\
0.19 * * * \\
(0.03)\end{array}$ & $\begin{array}{c}0.12^{* * *} \\
(0.01) \\
0.21^{* * *} \\
(0.03) \\
0.22^{* * *} \\
(0.03)\end{array}$ & $\begin{array}{c}0.12^{* * * *} \\
(0.01) \\
0.21^{* * *} \\
(0.03) \\
0.23^{* * *} \\
(0.03) \\
0.09^{* * *} \\
(0.03)\end{array}$ & $\begin{array}{c}0.10^{* * * *} \\
(0.01) \\
0.23 * * * \\
(0.03) \\
0.24 * * * \\
(0.03) \\
0.09 * * * \\
(0.03) \\
-0.11 * * * \\
(0.03) \\
0.65^{* * *} \\
(0.03)\end{array}$ \\
\hline $\begin{array}{l}\text { Observations } \\
\text { Adjusted } R^{2}\end{array}$ & $\begin{array}{l}756 \\
0.16\end{array}$ & $\begin{array}{l}756 \\
0.30\end{array}$ & $\begin{array}{l}756 \\
0.35\end{array}$ & $\begin{array}{l}756 \\
0.36\end{array}$ & $\begin{array}{l}756 \\
0.37\end{array}$ \\
\hline
\end{tabular}

$* * *, * *$, and $*$ indicate statistical significance at the $1 \%, 5 \%$, and $10 \%$ confidence levels, respectively. The results are estimated coefficients for a regression of cross-state trade barriers (in logs) on the stated variables. Panel I shows the results with distance as the infrastructural barrier and Panel II shows the results with the number of borders as the infrastructural barrier. The variables "High Corruption", "High Tax Administration", and "High Tax Rates" indicate whether either the importing or exporting state is in the top 10 percentile of Indian states with respect to these variables. 
Columns (2), (3), and (4) in Panel II show the result with the corruption, tax administration and tax rates dummies. The results are very similar to those in Panel II. All coefficients are around the same magnitude and are highly significant. An interesting difference with Panel I is that the adjusted $R^{2}$ is higher when including the policy barriers: 0.36 compared to 0.25 in column four. This is partly due to the higher explanatory power of the border effect, but also due to the higher explanatory power from the policy variables. Finally, column (5) includes the language barrier dummy variable. The results are similar to those in Panel I, although slightly smaller.

To summarize, I find that policy barriers to trade in the form of corruption, a burdensome tax administration, and tax rates are quantitatively as important as infrastructural barriers. Therefore, studying the nature and impact of these policy barriers is an important avenue for future research.

\section{Robustness}

I now perform two robustness exercises. The first is to allow for labor mobility across regions. The second is to recalibrate the model using trade barriers estimated from a gravity equation.

\subsection{Mobile Labor}

In the main analysis I assume labor is immobile across states and regions within state. I now relax the second assumption and allow for labor mobility across regions within a state. Nevertheless, I

assume that the wedge between agricultural and manufacturing wages, $\frac{w_{s}^{U}}{w_{s}^{R}}$, remains the same as the baseline calibration in each state. The procedure is as follows: given the same state population, $L_{s}$; labor wedge, $\frac{w_{s}^{U}}{w_{s}^{R}}$; parameter values $\sigma_{a}, \sigma_{m}, \theta_{a}, \theta_{m}$; and productivity vectors $T_{a, s}$ and $T_{m, s}, \mathrm{I}$ change specific trade barriers. Then, I recalculate the fraction of the rural population $\beta_{s}$ and rural wages $w_{a, s}$ such that (1) the urban wage in each is equal to the rural wage multiplied by the wage wedge and (2) labor markets clear.

Welfare is again measured as a compensating variation, but because labor within a state is now mobile, the weights on the compensating variation in each region will be different. Table 11 shows the impact on international trade and welfare, which is equivalent to Table 9, but with mobile labor across the rural and urban regions. In addition, it shows the fraction of the rural population and 
how it changed in response to each of the counterfactuals compared to the baseline calibration.

Table 11: International Trade and Welfare Impacts with Mobile Labor

\begin{tabular}{|c|c|c|c|c|c|c|}
\hline & Baseline & $\begin{array}{l}\text { Import } \\
\text { (1) }\end{array}$ & $\begin{array}{l}\text { Cross-State } \\
\text { to Port } \\
\text { (2) }\end{array}$ & $\begin{array}{l}\text { Cross- } \\
\text { State } \\
\text { (3) }\end{array}$ & $\begin{array}{l}\text { Rural- } \\
\text { Urban } \\
\text { (4) }\end{array}$ & $\begin{array}{l}\text { Cross-State } \\
\text { to U.S. } \\
\text { (5) }\end{array}$ \\
\hline \multicolumn{7}{|c|}{ International Imports } \\
\hline Aggregate & $17 \%$ & $43 \%$ & $28 \%$ & $12 \%$ & $20 \%$ & $16 \%$ \\
\hline Port States & $24 \%$ & $58 \%$ & $24 \%$ & $11 \%$ & $29 \%$ & $17 \%$ \\
\hline Non-Port States & $6 \%$ & $20 \%$ & $33 \%$ & $14 \%$ & $8 \%$ & $14 \%$ \\
\hline \multicolumn{7}{|l|}{ Welfare } \\
\hline Aggregate & . & $8 \%$ & $2 \%$ & $46 \%$ & $17 \%$ & $18 \%$ \\
\hline Port States & . & $14 \%$ & $-0 \%$ & $41 \%$ & $19 \%$ & $16 \%$ \\
\hline Non-Port States & . & $3 \%$ & $4 \%$ & $51 \%$ & $16 \%$ & $20 \%$ \\
\hline \multicolumn{7}{|c|}{ Rural Population $\beta$} \\
\hline Aggregate & 0.69 & 0.57 & 0.66 & 0.46 & 0.74 & 0.55 \\
\hline Port States & 0.60 & 0.44 & 0.60 & 0.41 & 0.69 & 0.49 \\
\hline Non-Port States & 0.77 & 0.69 & 0.72 & 0.51 & 0.78 & 0.60 \\
\hline
\end{tabular}

The middle panel in Table 11 shows that the main result holds even when labor is mobile across regions: India has more to gain from becoming more integrated internally than from removing international import barriers. Aggregate welfare gains from reducing cross-states barriers in India to the level of those in the United States amount to $18 \%$ (column (5)) compared to aggregate welfare gains of $8 \%$ from removing international import barriers (column (1)). This indicates that the effect on welfare is amplified under both counterfactuals compared to Table 9, but more for the case of domestic integration. The intuition is given in the bottom panel in Table 11. It shows that as cross-state trade barriers are reduced to the U.S. level (column (5)), labor reallocates more to 
the urban regions than when import barriers are completely removed. Hence, the welfare gains of removing internal barriers are amplified because workers in the urban regions face lower overall trade barriers, as both domestic as well as international trade occurs through the urban regions.

\subsection{Trade Barriers from the Gravity Equation}

Instead of using price variation to measure trade barriers, I can also compute trade barriers by estimating a gravity equation for both agricultural and manufacturing trade following Simonovska and Waugh (2014). Section A.6 of the online Appendix provides more detail on how these trade barriers are estimated. One drawback of this method is that it identifies cross-state trade barriers as the only internal trade barrier in India, as trade flows are disaggregated at the state level.

Table 12: Gravity Estimation Results

\begin{tabular}{|c|c|c|c|c|c|}
\hline & Baseline & $\begin{array}{l}\text { Import } \\
\text { (1) }\end{array}$ & $\begin{array}{l}\text { Cross-State } \\
\text { to Port } \\
\text { (2) }\end{array}$ & $\begin{array}{l}\text { Cross- } \\
\text { State } \\
\text { (3) }\end{array}$ & $\begin{array}{c}\text { Cross-State } \\
\text { to U.S. } \\
\text { (4) }\end{array}$ \\
\hline \multicolumn{6}{|c|}{ International Trade } \\
\hline Aggregate & $17 \%$ & $34 \%$ & $29 \%$ & $10 \%$ & $15 \%$ \\
\hline Port States & $28 \%$ & $57 \%$ & $27 \%$ & $10 \%$ & $22 \%$ \\
\hline Non-Port States & $1 \%$ & $2 \%$ & $32 \%$ & $9 \%$ & $4 \%$ \\
\hline \multicolumn{6}{|l|}{ Welfare } \\
\hline Aggregate & . & $7 \%$ & $4 \%$ & $66 \%$ & $19 \%$ \\
\hline Port States & . & $15 \%$ & $-0 \%$ & $53 \%$ & $16 \%$ \\
\hline Non-Port States & . & $-0 \%$ & $7 \%$ & $78 \%$ & $23 \%$ \\
\hline
\end{tabular}

Table 12 presents the results ${ }^{32}$ The main result still holds: the welfare gains from reducing internal barriers to trade to the level in the United States generates larger welfare gains than re-

\footnotetext{
${ }^{32}$ Because rural-urban trade barriers cannot be identified using the gravity estimation method, I cannot perform the counterfactual of removing them.
} 
moving international import barriers: $19 \%$ compared to $7 \%$, respectively. In addition, the welfare gains from reducing internal barriers are more equally distributed across Indian states.

\section{Conclusion}

This paper quantified the size of internal versus external trade barriers and assess the effect on trade and welfare. I developed a quantitative multi-sector international trade model featuring nonhomothetic preferences in which Indian states trade both domestically and internationally. I discipline the model using rich micro data on price dispersion as well as foreign and domestic trade flows at the Indian state level.

I find that internal trade barriers make up a substantial part of the total trade barrier: on average, they account for $40 \%$, with large heterogeneity across Indian states depending on the distance to the closest port. Second, I find that the welfare gains from reducing cross-state trade barriers to the level in the U.S. are larger than from removing international import barriers: $13 \%$ versus $7 \%$, respectively. In other words, India has more to gain from becoming more integrated domestically than from removing international import barriers. In addition, the largest welfare gains from domestic integration are associated with reducing trade barriers between Indian states.

The next step is to study the components of these cross-state trade barriers. I provided some evidence that cross-state trade barriers not only consist of infrastructural barriers but also of policy barriers. Given that policy barriers such as corruption and a burdensome tax administration plague many developing countries, studying the size and nature of policy barriers and their interaction with infrastructure is an important avenue for future research.

\section{References}

Adamopoulos, T. (2011): “Transportation Costs, Agricultural Productivity and Cross-Country Income Differences," International Economic Review, 52, 489-521.

AldER, S. (2016): “Chinese Roads in India: The Effect of Transport Infrastructure on Economic Development," Working paper. 
Allen, T. (2014): “Information Frictions in Trade,” Econometrica, 82, 2041-2083.

Allen, T. And C. ARKolakis (2014): "Trade and the Topography of the Spatial Economy," Quarterly Journal of Economics, 129, 1085-1140.

Alvarez, F. AND R. E. LuCAS (2007): “General Equilibrium Analysis of the Eaton-Kortum Model of International Trade," Journal of Monetary Economics, 54, 1726-1768.

Arkolakis, C., A. Costinot, And A. Rodríguez-Clare (2011): "New Trade Models, Same Old Gains?” American Economic Review, 102, 94-130.

Asturias, J., M. García-SAntana, And R. Roberto (2016): “Competition and the Welfare Gains from Transportation Infrastructure: Evidence from the Golden Quadrilateral of India," Working paper.

ATKIN, D. (2013): “Trade, Tastes and Nutrition in India,” American Economic Review, 103, 1629_ 1663.

AtKin, D. And D. Donaldson (2016): “Who’s Getting Globalized? The Size and Impact of Intranational Trade Costs," NBER Working Paper No. 21439.

Behrens, K., C. Gaigné, G. I. P. Ottaviano, And T. Jacques-François (2006): “Is remoteness a Locational Disadvantage?” Journal of Economic Geography, 6, 347-368.

Caliendo, L., F. Parro, E. Rossi-Hansberg, and P.-D. Sarte (2014): “The Impact of Regional and Sectoral Productivity Changes on the U.S. Economy,” NBER Working Paper No. 20168.

Caron, J., T. Fally, And J. R. Markusen (2014): “International Trade Puzzles: A Solution Linking Production and Preferences," Quarterly Journal of Economics, 129, 1501-1552.

CoçAR, A. K. And P. D. FAjgelbaum (2016): "Internal Geography, International Trade, and Regional Outcomes," American Economic Journal: Microeconomics, 8, 24-56.

Costinot, A. And D. Donaldson (2014): "How Large are the Gains from Economic Integration? Theory and Evidence from U.S. Agriculture, 1880-1997,' Working paper. 
Crucini, M. J. And M. Shintani (2008): "Persistence in Law of One Price Deviations: Evidence from Micro-Data," Journal of Monetary Economics, 55, 629-644.

DATA PORTAL OF India (2012): “Agricultural Marketing Information Network,” .

Directorate General of Commercial Intelligence and Statistics, Ministry of COMmerce And Industry (2012a): “Foreign Trade Statistics of India,” .

_ (2012b): “The Inter-State Movements/Flows of Goods by Rail, River and Air,” .

DonAlDSON, D. (2016): "Railroads of the Raj: Estimating the Impact of Transportation Infrastructure," American Economic Review, forthcoming.

Donaldson, D. AND R. Hornbeck (2016): "Railroads and American Economic Growth: A Market Access Approach," Quarterly Journal of Economics, 131, 799-858.

Dornbusch, R., S. Fischer, And P. A. S Amuelson (1977): “Comparative Advantage, Trade, and Payments in a Ricardian Model with a Continuum of Goods," American Economic Review, 67, 823-839.

EAton, J. And S. Kortum (2002): “Technology, Geography, and Trade,” Econometrica, 70, 1741-1779.

Engel, C. And J. H. Rogers (1996): “How Wide Is the Border?” American Economic Review, $86,1112-1125$.

Feenstra, R. C. And D. E. Weinstein (2016): “Globalization, Markups, and the U.S. Price Level," Journal of Political Economy, forthcoming.

FIELER, A. C. (2011): "Non-homotheticity and Bilateral Trade: Evidence and a Quantitative Explanation," Econometrica, 79, 1069-1101.

Gollin, D., D. Lagakos, And M. Waugh (2014): “The Agricultural Productivity Gap in Poor Countries," Quarterly Journal of Economics, 129, 939-993. 
Gollin, D. And R. Rogerson (2014): "Productivity, Transport Costs, and Subsistence Agriculture," Journal of Development Economics, 107, 38-48.

Herrendorf, B., J. A. Schmitz, And A. Teixeira (2010): “The Role of Transportation in U.S. Economic Development: 1840-1860,” International Economic Review, 53, 693-716.

Hummels, D. And G. Schaur (2013): “Time as a Trade Barrier,” American Economic Review, $103,1-27$.

Jensen, R. (2007): “The Digital Provide: Information (Technology), Market Performance, and Welfare in the South Indian Fisheries Sector," Quarterly Journal of Economics, 122, 879-924.

LimÃo, N. AND A. J. Venables (1999): “Infrastructure, Geographical Disadvantage, and Transport Costs, and Trade," The World Bank Economic Review, 15, 451-479.

NAGY, D. (2016): “City location and economic development,” Working paper.

Ramondo, N., A. Rodríguez-Clare, And M. SABorío-RodríGuez (2016): “Trade, Domestic Frictions, and Scale Effects.” American Economic Review, forthcoming.

RestucciA, D., D. T. Y. YAng, And X. Zhu (2008): “Agriculture and Aggregate Productivity: A Quantitative Cross-Country Analysis,” Journal of Monetary Economics, 55, 234-250.

Rossi-Hansberg, E. (2005): “A Spatial Theory of Trade,” American Economic Review, 95, 1464-1491.

SimonovsKa, I. AND M. WAUGH (2014): "The Elasticity of Trade: Estimates and Evidence," Journal of International Economics, 92, 34-50.

Sotelo, S. (2016): “Domestic Trade Frictions and Agriculture,” Working paper.

StOREYGARD, A. (2016): "Farther on Down the Road: Transport Costs, Trade and Urban Growth," Review of Economic Studies, 83, 1263-1295.

THE WORLD BANK (2014): “Enterprise Surveys,” . 
Tombe, T. (2015): “The Missing Food Problem: Trade, Agriculture, and International Productivity Differences," American Economic Journal: Macroeconomics, 7, 226-258.

Tombe, T. And X. Zhu (2015): “Trade, Migration and Productivity: A Quantitative Analysis of China," Working paper.

United NATIONS (2012): “Industrial Statistical Database," .

United States Department of Agriculture (2012): "National Aggregate Statistics Service in the Agricultural Prices," .

Waugh, M. (2010): “International Trade and Income Differences,” American Economic Review, 99, 2093-2124. 


\section{Appendix for Online Publication}

This online appendix contains additional empirical results, robustness tests, and a mathematical proof for the paper, "A Passage to India: Quantifying Internal and External Barriers to Trade" by Van Leemput. I have organized the results into the following sections: (A.1) additional data, (A.2) price data, (A.3) state-based barriers to international trade, (A.4) international trade results by sector, (A.5) model without port differential port access, (A.6) gravity equation estimation, and (A.7) welfare.

\section{A.1 Additional Data}

Figure A.1 shows a map with all 27 Indian states and three union territories used for the analysis.

Figure A.1: Indian States

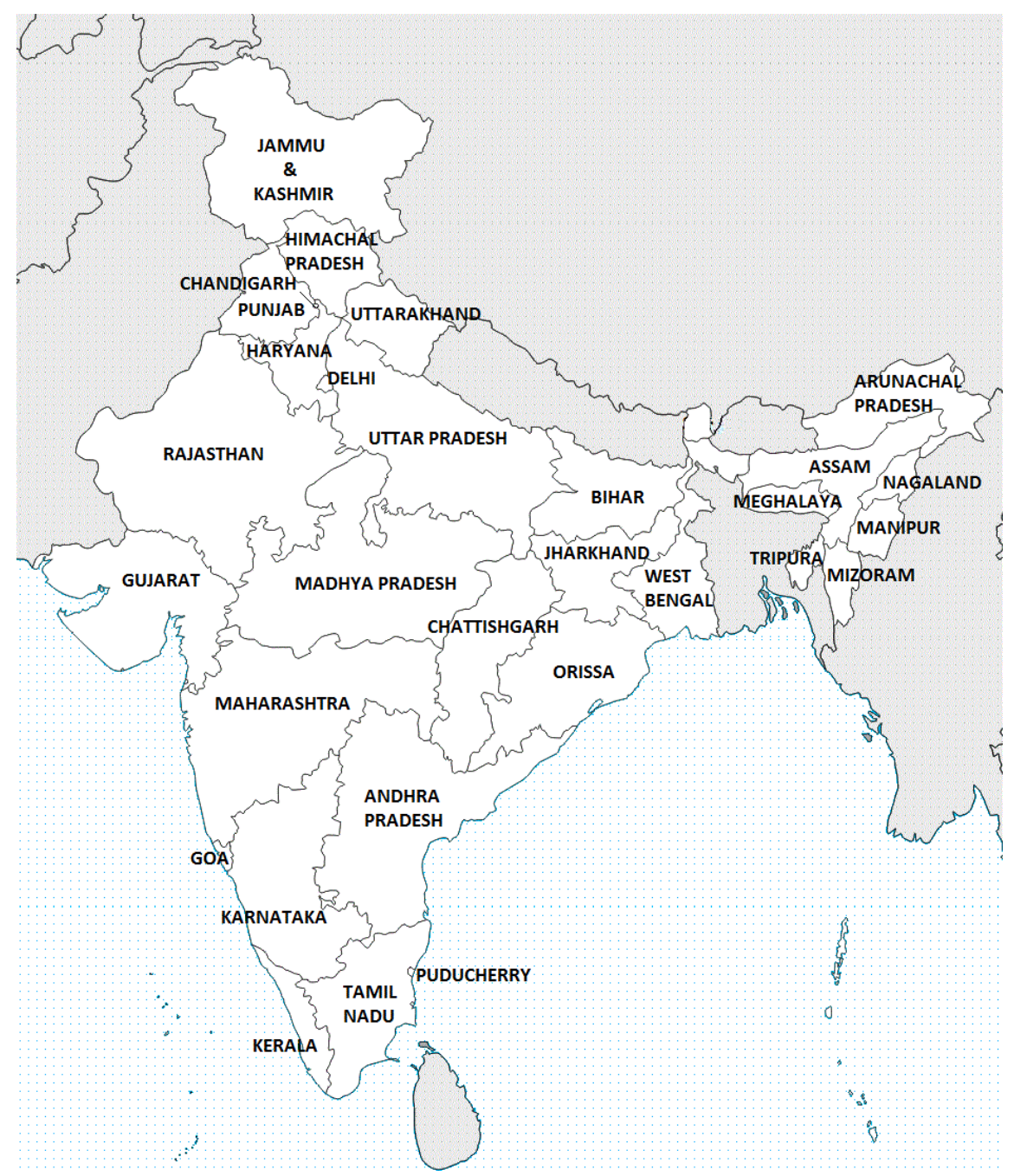


Table A.1 provides additional state-based data used in the model calibration.

Table A.1: Data Model

\begin{tabular}{|c|c|c|c|c|}
\hline & $\begin{array}{c}\text { Total Pop. } \\
L_{s} \\
\end{array}$ & $\begin{array}{l}\text { Share Rural Pop. } \\
\beta_{s}\end{array}$ & $\begin{array}{c}\text { Rural Wage } \\
w_{s}^{R} \\
\end{array}$ & $\begin{array}{c}\text { Urban wage } \\
w_{s}^{U} \\
\end{array}$ \\
\hline Andhra Pradesh & $84,665,533$ & $67 \%$ & 0.28 & 0.67 \\
\hline Arunachal Pradesh & $1,382,611$ & $77 \%$ & 0.30 & 0.97 \\
\hline Assam & $31,169,272$ & $86 \%$ & 0.12 & 0.82 \\
\hline Bihar & $103,804,637$ & $89 \%$ & 0.06 & 0.60 \\
\hline Chandigarh & $1,054,686$ & $3 \%$ & 0.51 & 0.65 \\
\hline Chattishgarh & $25,540,196$ & $77 \%$ & 0.17 & 0.64 \\
\hline Delhi & $16,753,235$ & $3 \%$ & 0.60 & 0.52 \\
\hline Goa & $1,457,723$ & $38 \%$ & 0.35 & 1.14 \\
\hline Gujarat & $60,383,628$ & $57 \%$ & 0.34 & 0.66 \\
\hline Haryana & $25,353,081$ & $65 \%$ & 0.39 & 0.98 \\
\hline Himachal Pradesh & $6,856,509$ & $90 \%$ & 0.25 & 1.36 \\
\hline Jammu and Kashmir & $12,548,926$ & $73 \%$ & 0.17 & 0.55 \\
\hline Jharkhand & $32,966,238$ & $76 \%$ & 0.08 & 0.52 \\
\hline Karnataka & $61,130,704$ & $61 \%$ & 0.23 & 0.56 \\
\hline Kerala & $33,387,677$ & $52 \%$ & 0.25 & 0.55 \\
\hline Madhya Pradesh & $72,597,565$ & $72 \%$ & 0.16 & 0.45 \\
\hline Maharashtra & $112,372,972$ & $55 \%$ & 0.27 & 0.68 \\
\hline Manipur & $2,721,756$ & $70 \%$ & 0.17 & 0.37 \\
\hline Meghalaya & $2,964,007$ & $80 \%$ & 0.12 & 0.79 \\
\hline Mizoram & $1,091,014$ & $48 \%$ & 0.22 & 0.37 \\
\hline Nagaland & $1,980,602$ & $71 \%$ & 0.25 & 0.66 \\
\hline Orissa & $41,947,358$ & $83 \%$ & 0.13 & 0.88 \\
\hline Puducherry & $1,244,464$ & $32 \%$ & 0.24 & 0.49 \\
\hline Punjab & $27,704,236$ & $63 \%$ & 0.46 & 0.71 \\
\hline Rajasthan & $68,621,012$ & $75 \%$ & 0.22 & 0.68 \\
\hline Tamil Nadu & $72,138,958$ & $52 \%$ & 0.25 & 0.55 \\
\hline Tripura & $3,671,032$ & $74 \%$ & 0.15 & 0.63 \\
\hline Uttar Pradesh & $199,581,477$ & $78 \%$ & 0.13 & 0.44 \\
\hline Uttarakhand & $10,116,752$ & $69 \%$ & 0.19 & 0.91 \\
\hline West Bengal & $91,347,736$ & $68 \%$ & 0.19 & 0.53 \\
\hline Rest of World (RoW) & $579,144,440,361,130,704$ & $40 \%$ & 1 & 1.88 \\
\hline
\end{tabular}




\section{A.2 Price Data}

Tables A.2 and A.3 show the list of agricultural goods used in the analysis in India and the United States, respectively.

Table A.2: Agricultural Goods in India

\begin{tabular}{|c|c|c|c|}
\hline 1. & Apple & 28. & Mango \\
\hline 2. & Arhar (Tur) & 29. & Masur Dal \\
\hline 3. & Bajra (Pearl Millet) & 30. & Mousambi \\
\hline 4. & Banana & 31. & Onion \\
\hline 5. & Beetroot & 32. & Orange \\
\hline 6. & Bengal Grams (Gram) & 33. & Paddy (Dhan) \\
\hline 7. & Bhindi (Ladies Finger) & 34. & Papaya \\
\hline 8./9. & Bitter gourd (Two Varieties) & 27. & Maize \\
\hline 10. & Black Grams (Urd Beans) & 35. & Peach \\
\hline 11. & Bottle gourd & 36. & Pears \\
\hline $12 . / 13$. & Cabbage (Two Varieties) & 37. & Pomegranate \\
\hline 14./15. & Carrot (Two Varieties) & 38. & Potato \\
\hline 16. & Cauliflower & 39./40. & Pumpkin (Two Varieties) \\
\hline 17. & Cucumber & 41./42. & Raddish (Two Varieties) \\
\hline 18. & French Beans & 43. & Red Grams \\
\hline 19. & Garlic & 44. & Rice \\
\hline 20. & Ginger & 45 . & Spinach \\
\hline 21./22. & Green Chilly (Two Varieties) & 46. & Tomato (Local) \\
\hline 23. & Green Grams (Moong) & 47. & Tomato \\
\hline 24. & Green ginger & 48. & Turmeric \\
\hline 25. & Gur (Jaggery) & 49. & Water Melon \\
\hline 26. & Lemon & 50. & Wheat \\
\hline 27. & Maize & & \\
\hline
\end{tabular}


Table A.3: Agricultural Goods in the United States

\begin{tabular}{llll}
\hline \hline 1./4. & Barley (Four Varieties) & 18. & Peanuts \\
5. & Canola & $19 . / 21$. & Peas (Three Varieties) \\
6. & Corn, Grain & 22. & Rice \\
7. & Cotton, Cottonseed & 23. & Rye \\
8. & Flaxseed & 24. & Safflower \\
9./11. & Hay (Three Varieties) & 25. & Sorghum, grain \\
12. & Hops & 26. & Soybeans \\
13. & Lentils & 27. & Sugarbeets \\
14. & Maple syrup & 28. & Sugarcane \\
15. & Millet, proso & $29 . / 31$. & Sunflower (Three Varieties) \\
16. & Mint (Two Varieties) & $32 . / 36$. & Tobacco (Five Varieties) \\
17. & Oats & $37 . / 40$. & Wheat (Four Varieties) \\
\hline \hline
\end{tabular}

\section{A.3 State-based Barriers to International Trade}

Tables A.4, A.5, A.6, A.7 show the state-based (categorized under port versus non-port states) results for the internal trade barriers as a fraction of the total trade barrier for agricultural and manufacturing imports and exports, respectively. 
Table A.4: Agricultural Import Trade Barriers

\begin{tabular}{|c|c|c|}
\hline Port States & $\begin{array}{c}\text { Total Import Barrier } \\
\left(1-\beta_{s}\right) * \tau_{a, i m p}+ \\
\beta_{s} * \delta_{s} * \tau_{a, i m p}\end{array}$ & $\begin{array}{c}\text { \% Internal } \\
\left(1-\beta_{s}\right)+ \\
\beta_{s} * \delta_{s}\end{array}$ \\
\hline Median & 3.07 & $11 \%$ \\
\hline Andhra Pradesh & 3.09 & $11 \%$ \\
\hline Delhi & 2.57 & $0 \%$ \\
\hline Goa & 2.92 & $8 \%$ \\
\hline Gujarat & 3.05 & $11 \%$ \\
\hline Karnataka & 3.14 & $12 \%$ \\
\hline Kerala & 3.31 & $16 \%$ \\
\hline Maharashtra & 2.95 & $9 \%$ \\
\hline Orissa & 3.47 & $18 \%$ \\
\hline Tamil Nadu & 2.89 & $7 \%$ \\
\hline West Bengal & 4.68 & $34 \%$ \\
\hline Non-Port States & $\begin{array}{c}\text { Total Import Barrier } \\
\left(1-\beta_{s}\right) * d_{s, l} * \tau_{a, i m p}+ \\
\beta_{s} * \delta_{s} * d_{s, l} * \tau_{a, i m p} \\
\end{array}$ & $\begin{array}{c}\text { \% Internal } \\
\left(1-\beta_{s}\right) * d_{s, l}+ \\
\beta_{s} * \delta_{s} * d_{s, l} \\
\end{array}$ \\
\hline Median & 6.95 & $52 \%$ \\
\hline Arunachal Pradesh & 8.19 & $58 \%$ \\
\hline Assam & 10.6 & $67 \%$ \\
\hline Bihar & 3.98 & $26 \%$ \\
\hline Chandigarh & 3.77 & $23 \%$ \\
\hline Chattishgarh & 4.26 & $30 \%$ \\
\hline Haryana & 4.95 & $37 \%$ \\
\hline Himachal Pradesh & 15.1 & $76 \%$ \\
\hline Jammu and Kashmir & 12.8 & $72 \%$ \\
\hline Jharkhand & 6.22 & $48 \%$ \\
\hline Madhya Pradesh & 4.56 & $33 \%$ \\
\hline Manipur & 7.96 & $57 \%$ \\
\hline Meghalaya & 13.1 & $72 \%$ \\
\hline Mizoram & 7.68 & $56 \%$ \\
\hline Nagaland & 8.17 & $58 \%$ \\
\hline Puducherry & 3.04 & $11 \%$ \\
\hline Punjab & 4.68 & $34 \%$ \\
\hline Rajasthan & 5.21 & $40 \%$ \\
\hline Tripura & 9.01 & $62 \%$ \\
\hline Uttar Pradesh & 3.87 & $24 \%$ \\
\hline Uttarakhand & 10.3 & $66 \%$ \\
\hline
\end{tabular}


Table A.5: Manufacturing Import Trade Barriers

\begin{tabular}{|c|c|c|}
\hline Port States & $\begin{array}{c}\text { Total Import Barrier } \\
\left(1-\beta_{s}\right) * \tau_{m, i m p}+ \\
\beta_{s} * \delta_{s} * \tau_{m, i m p}\end{array}$ & $\begin{array}{c}\% \text { Internal } \\
\left(1-\beta_{s}\right)+ \\
\beta_{s} * \delta_{s}\end{array}$ \\
\hline Median & 1.77 & $29 \%$ \\
\hline Andhra Pradesh & 1.79 & $29 \%$ \\
\hline Delhi & 1.49 & $0 \%$ \\
\hline Goa & 1.69 & $22 \%$ \\
\hline Gujarat & 1.76 & $28 \%$ \\
\hline Karnataka & 1.81 & $31 \%$ \\
\hline Kerala & 1.91 & $37 \%$ \\
\hline Maharashtra & 1.70 & $23 \%$ \\
\hline Orissa & 2.01 & $42 \%$ \\
\hline Tamil Nadu & 1.67 & $21 \%$ \\
\hline West Bengal & 2.71 & $63 \%$ \\
\hline Non-Port States & $\begin{array}{c}\text { Total Import Barrier } \\
\left(1-\beta_{s}\right) * d_{s, l} * \tau_{m, i m p}+ \\
\beta_{s} * \delta_{s} * d_{s, l} * \tau_{m, i m p} \\
\end{array}$ & $\begin{array}{c}\text { \% Internal } \\
\left(1-\beta_{s}\right) * d_{s, l}+ \\
\beta_{s} * \delta_{s} * d_{s, l} \\
\end{array}$ \\
\hline Median & 4.02 & $78 \%$ \\
\hline Arunachal Pradesh & 4.74 & $82 \%$ \\
\hline Assam & 6.14 & $87 \%$ \\
\hline Bihar & 2.30 & $53 \%$ \\
\hline Chandigarh & 2.18 & $49 \%$ \\
\hline Chattishgarh & 2.46 & $58 \%$ \\
\hline Haryana & 2.86 & $66 \%$ \\
\hline Himachal Pradesh & 8.74 & $91 \%$ \\
\hline Jammu and Kashmir & 7.40 & $89 \%$ \\
\hline Jharkhand & 3.59 & $75 \%$ \\
\hline Madhya Pradesh & 2.64 & $62 \%$ \\
\hline Manipur & 4.60 & $81 \%$ \\
\hline Meghalaya & 7.57 & $89 \%$ \\
\hline Mizoram & 4.44 & $80 \%$ \\
\hline Nagaland & 4.72 & $82 \%$ \\
\hline Puducherry & 1.76 & $28 \%$ \\
\hline Punjab & 2.70 & $63 \%$ \\
\hline Rajasthan & 3.01 & $68 \%$ \\
\hline Tripura & 5.21 & $84 \%$ \\
\hline Uttar Pradesh & 2.24 & $51 \%$ \\
\hline Uttarakhand & 5.94 & $86 \%$ \\
\hline
\end{tabular}


Table A.6: Agricultural Export Trade Barriers

\begin{tabular}{lc|c}
\hline \hline Port States & Total Export Barrier & \% Internal \\
& $\delta_{s} * \tau_{a, \text { exp }}$ & $\delta_{s}$ \\
\hline Median & 2.88 & $23 \%$ \\
\hline Andhra Pradesh & 2.79 & $21 \%$ \\
Delhi & 2.14 & $0 \%$ \\
Goa & 2.93 & $24 \%$ \\
Gujarat & 2.84 & $22 \%$ \\
Karnataka & 2.92 & $24 \%$ \\
Kerala & 3.32 & $32 \%$ \\
Maharashtra & 2.72 & $19 \%$ \\
Orissa & 3.05 & $27 \%$ \\
Tamil Nadu & 2.66 & $18 \%$ \\
West Bengal & 4.73 & $51 \%$ \\
\hline \hline Non-Port States & Total Export Barrier & $\%$ Internal \\
& $* d_{l, s} * \tau_{a, e x p}$ & $\delta_{s} * d_{l, s}$ \\
\hline Median & 6.62 & $65 \%$ \\
\hline Arunachal Pradesh & 7.50 & $69 \%$ \\
Assam & 9.67 & $75 \%$ \\
Bihar & 3.41 & $34 \%$ \\
Chandigarh & 3.14 & $29 \%$ \\
Chattishgarh & 3.77 & $40 \%$ \\
Haryana & 4.51 & $49 \%$ \\
Himachal Pradesh & 13.4 & $82 \%$ \\
Jammu and Kashmir & 12.6 & $81 \%$ \\
Jharkhand & 5.74 & $60 \%$ \\
Madhya Pradesh & 4.16 & $45 \%$ \\
Manipur & 7.53 & $69 \%$ \\
Meghalaya & 12.5 & $81 \%$ \\
Mizoram & 8.36 & $72 \%$ \\
Nagaland & 7.73 & $70 \%$ \\
Puducherry & 2.93 & $24 \%$ \\
Punjab & 4.46 & $49 \%$ \\
Rajasthan & 4.76 & $52 \%$ \\
Tripura & 8.57 & $72 \%$ \\
Uttar Pradesh & $34 \%$ \\
Uttarakhand & & $76 \%$ \\
\hline \hline & & \\
\hline
\end{tabular}


Table A.7: Manufacturing Export Trade Barriers

\begin{tabular}{lc|c}
\hline \hline Port States & Total Export Barrier & $\begin{array}{c}\text { Internal } \\
\text { N/A }\end{array}$ \\
\hline Median & 2.92 & $\cdot$ \\
\hline Andhra Pradesh & 2.92 & $\cdot$ \\
Delhi & 2.92 & $\cdot$ \\
Goa & 2.92 & $\cdot$ \\
Gujarat & 2.92 & $\cdot$ \\
Karnataka & 2.92 & $\cdot$ \\
Kerala & 2.92 & $\cdot$ \\
Maharashtra & 2.92 & $\cdot$ \\
Orissa & 2.92 & $\cdot$ \\
Tamil Nadu & 2.92 & $\cdot$ \\
West Bengal & 2.92 & $\cdot$ \\
\hline \hline Non-Port States & Total Export Barrier & $\%$ Internal \\
& $d_{l, s} * \tau_{m, e x p}$ & $d_{l, s}$ \\
\hline Median & 5.00 & $27 \%$ \\
\hline Arunachal Pradesh & 6.22 & $37 \%$ \\
Assam & 5.33 & $30 \%$ \\
Bihar & 3.52 & $10 \%$ \\
Chandigarh & 4.28 & $20 \%$ \\
Chattishgarh & 3.82 & $14 \%$ \\
Haryana & 4.63 & $24 \%$ \\
Himachal Pradesh & 7.16 & $43 \%$ \\
Jammu and Kashmir & 7.51 & $45 \%$ \\
Jharkhand & 4.66 & $24 \%$ \\
Madhya Pradesh & 3.92 & $15 \%$ \\
Manipur & 6.24 & $37 \%$ \\
Meghalaya & 6.56 & $39 \%$ \\
Mizoram & 6.23 & $37 \%$ \\
Nagaland & 6.22 & $37 \%$ \\
Puducherry & 3.21 & $5 \%$ \\
Punjab & 4.04 & $17 \%$ \\
Rajasthan & 4.22 & $19 \%$ \\
Tripura & 6.22 & $37 \%$ \\
Uttar Pradesh & 3.52 & $10 \%$ \\
Uttarakhand & & $46 \%$ \\
\hline \hline & & \\
\hline
\end{tabular}




\section{A.4 International Trade Results by Sector}

Table A.8 shows the import and export effects in response to all counterfactuals studied in Section

5.2. It breaks down the overall trade effects into the sectoral imports and exports for all states, broken down by port and non-port states.

Table A.8: International Sectoral Imports and Exports Impact

\begin{tabular}{|c|c|c|c|c|c|c|c|}
\hline & & Baseline & $\begin{array}{c}\text { Import } \\
\text { (1) }\end{array}$ & $\begin{array}{l}\text { Cross-State } \\
\text { to Port } \\
\text { (2) }\end{array}$ & $\begin{array}{l}\text { Cross- } \\
\text { State } \\
\text { (3) }\end{array}$ & $\begin{array}{l}\text { Rural- } \\
\text { Urban } \\
\text { (4) }\end{array}$ & $\begin{array}{c}\text { Cross-State } \\
\text { to U.S. } \\
\text { (5) }\end{array}$ \\
\hline \multicolumn{8}{|l|}{ Aggregate } \\
\hline \multirow[t]{2}{*}{ Agriculture } & Import & $3 \%$ & $33 \%$ & $4 \%$ & $1 \%$ & $2 \%$ & $1 \%$ \\
\hline & Export & $6 \%$ & $22 \%$ & $10 \%$ & $8 \%$ & $22 \%$ & $8 \%$ \\
\hline \multirow[t]{2}{*}{ Manufacturing } & Import & $27 \%$ & $39 \%$ & $54 \%$ & $23 \%$ & $45 \%$ & $23 \%$ \\
\hline & Export & $24 \%$ & $47 \%$ & $49 \%$ & $16 \%$ & $28 \%$ & $16 \%$ \\
\hline \multicolumn{8}{|l|}{ Port States } \\
\hline \multirow[t]{2}{*}{ Agriculture } & Import & $4 \%$ & $49 \%$ & $4 \%$ & $1 \%$ & $3 \%$ & $1 \%$ \\
\hline & Export & $10 \%$ & $33 \%$ & $10 \%$ & $8 \%$ & $31 \%$ & $8 \%$ \\
\hline \multirow[t]{2}{*}{ Manufacturing } & Import & $36 \%$ & $51 \%$ & $36 \%$ & $16 \%$ & $45 \%$ & $16 \%$ \\
\hline & Export & $33 \%$ & $60 \%$ & $33 \%$ & $12 \%$ & $29 \%$ & $12 \%$ \\
\hline \multicolumn{8}{|l|}{ Non-Port States } \\
\hline \multirow[t]{2}{*}{ Agriculture } & Import & $1 \%$ & $15 \%$ & $4 \%$ & $1 \%$ & $1 \%$ & $1 \%$ \\
\hline & Export & $2 \%$ & $8 \%$ & $10 \%$ & $7 \%$ & $9 \%$ & $7 \%$ \\
\hline \multirow[t]{2}{*}{ Manufacturing } & Import & $11 \%$ & $20 \%$ & $49 \%$ & $19 \%$ & $16 \%$ & $19 \%$ \\
\hline & Export & $10 \%$ & $25 \%$ & $44 \%$ & $13 \%$ & $8 \%$ & $13 \%$ \\
\hline
\end{tabular}




\section{A.5 Model without Differential Port Access}

To quantitatively assess the importance of differential international port access across Indian states, I estimate the entire model without distinguishing states with differential access to an international port, that is, all states have an international port. I recalibrate the four international trade costs: agricultural and manufacturing import and export costs, denoted by $\tau_{a, i m p}, \tau_{m, i m p}, \tau_{a, \text { exp }}$ and $\tau_{m, e x p}$, respectively, in order to match the same aggregate import and export shares as a fraction of sectoral production for agriculture and manufacturing, as shown in Table 4. Table A.9 shows the international trade barriers in a recalibrated model without taking into account differential port access across Indian states. Compared to the border costs in Table 6, the estimated international import cost are almost $40 \%$ higher for agriculture and $60 \%$ for manufacturing, whereas the export trade barriers are similar. As shown in Table 7, the "old model" does significantly worse in capturing international trade for port versus non-port states in India.

Table A.9: Border Trade Barriers without Differential Port Access

\begin{tabular}{c|cc}
\hline \hline & Agriculture & Manufacturing \\
\hline Import & $\tau_{a, i m p}=3.13$ & $\tau_{m, i m p}=1.79$ \\
Export & $\tau_{a, \exp }=2.12$ & $\tau_{m, \exp }=2.98$ \\
\hline \hline
\end{tabular}

Next, I perform the same counterfactual exercise of removing international import barriers in India, as given in column one of Table 9. The counterfactual results in a model without differential access to international ports across Indian states are presented in Table A.10. An interesting thing to note is that the welfare gains from removing international import barriers are higher: $13 \%$ on aggregate compared to $7 \%$ in Table 9 . Thus, a model without heterogeneous port access, would overestimate the welfare gains by 6 percentage points. In addition, the welfare gains are equally distributed among port and non-port states, which is intuitive because they are no longer differentiated by whether they have access to an international port or not. Therefore, these results show that to assess the aggregate and distributional welfare gains from international integration, it is important to include differential port access. 
Table A.10: International Trade and Welfare Impacts without Differential Port Access

\begin{tabular}{|c|c|c|c|c|c|}
\hline & Baseline & $\begin{array}{l}\text { Import } \\
\text { (1) }\end{array}$ & $\begin{array}{l}\text { Cross- } \\
\text { State } \\
\text { (2) }\end{array}$ & $\begin{array}{l}\text { Rural- } \\
\text { Urban } \\
\text { (3) }\end{array}$ & $\begin{array}{c}\text { Cross-State } \\
\text { to U.S. } \\
\text { (4) }\end{array}$ \\
\hline \multicolumn{6}{|c|}{ International Imports } \\
\hline Aggregate & $17 \%$ & $48 \%$ & $6 \%$ & $22 \%$ & $10 \%$ \\
\hline Port States & $16 \%$ & $48 \%$ & $7 \%$ & $19 \%$ & $10 \%$ \\
\hline Non-Port States & $18 \%$ & $48 \%$ & $6 \%$ & $25 \%$ & $10 \%$ \\
\hline \multicolumn{6}{|l|}{ Welfare } \\
\hline Aggregate & $\cdot$ & $13 \%$ & $29 \%$ & $19 \%$ & $12 \%$ \\
\hline Port States & $\cdot$ & $14 \%$ & $31 \%$ & $18 \%$ & $13 \%$ \\
\hline Non-Port States & · & $13 \%$ & $27 \%$ & $20 \%$ & $12 \%$ \\
\hline
\end{tabular}

\section{A.6 Gravity Equation Estimation}

As a robustness check, I estimate two separate gravity equations in order to compute the trade barriers directly from the trade flows. Following Simonovska and Waugh (2014), I assume that there is a representative consumer in each state in India that has a CES preference for each good (agriculture and manufacturing):

$$
U_{s}=\left[\int_{0}^{1} q_{s}(j)^{\frac{\sigma-1}{\sigma}} d j\right]^{\frac{\sigma-1}{\sigma}}
$$


Each state draws a good-specific productivity $z_{s}$ from a state-specific distribution for each variety, $j$. I assume this distribution is Fréchet:

$$
z_{s}(j) \sim F_{s}(z)=\exp \left(-T_{s} z_{s}^{-\theta}\right)
$$

If production in both sectors has constant returns to scale (CRS) and labor is immobile across states, then the unit cost for a specific variety $j$ is

$$
\frac{w_{s}}{z_{s}(j)}
$$

Each Indian state trades with other Indian states at a per-unit iceberg trade $\operatorname{cost} \tau_{s l}>1$ to ship goods from state $l$ to state $s$. Therefore, the total price of an imported good variety $j$ from state $l$ is

$$
p_{s l}=\frac{\tau_{s l} w_{l}}{z_{l}(j)}
$$

Consumers purchase from the lowest cost producer, which implies

$$
p_{s}(j)=\min \left\{p_{s l}\left(j_{g}\right) ; l=1 \ldots S\right\}
$$

The CES exact price index for each destination $s$ is given by

$$
P_{s}=\left[\Gamma\left(\frac{\theta+1-\sigma}{\theta}\right)\right]^{\frac{1}{1-\sigma}}\left[\sum_{l=1}^{S}\left[T_{l}\left(w_{l} \tau_{s l}\right)^{-\theta}\right]\right]^{-\frac{1}{\theta}}
$$

Then, the share of expenditures that state $s$ spends on goods from state $l, \pi_{s l}$, can be written as follows

$$
\pi_{s l}=\frac{X_{s l}}{X_{s}}=\frac{T_{l}\left(w_{l} \tau_{s l}\right)^{-\theta}}{\sum_{l=1}^{S}\left[T_{l}\left(w_{l} \tau_{s l}\right)^{-\theta}\right]}
$$

Divide the expenditure share for state $s$ on goods from state $l$ by the expenditure share for state $s$ on its own goods:

$$
\frac{X_{s l} / X_{s}}{X_{s s} / X_{s}}=\frac{T_{l} w_{l}^{-\theta}}{T_{s} w_{s}^{-\theta}} \tau_{s l}^{-\theta} .
$$


Take logs to derive the theoretical gravity equation:

$$
\log \left(\frac{X_{s l} / X_{s}}{X_{s s} / X_{s}}\right)=S_{l}-S_{s}-\theta \log \tau_{s l}
$$

where $S_{l}=T_{l} w_{l}^{-\theta}$ and $S_{s}=T_{s} w_{s}^{-\theta}$. The empirical gravity equation can be written as

$$
\log \left(\frac{X_{s l} / X_{s}}{X_{s s} / X_{s}}\right)=S_{l}-S_{s}-\theta \log \tau_{s l}+\nu_{s l}
$$

I assume that trade costs take the following functional form:

$$
\log \tau_{s l}=d_{k}+b_{s l}+e x_{l}
$$

where $d_{k}$ with $k=1,2, \ldots, 5$ is the effect of distance between the capitals of state $s$ and $l$ lying in the $k$ th distance interval, and $b_{s l}$ is a dummy variable that indicates whether states share a border. Finally, $e x_{l}$ is an exporter fixed effect that allows for asymmetric trade costs at the exporter level. By estimating the gravity equation, I obtain the trade barriers $\log \hat{\tau}_{s l}$ up to a constant $\theta$. I previously estimated the trade elasticity for agriculture, using the methods in Simonovska and Waugh (2014) to be 5.6. For manufacturing I fix it at 5, following the literature. Hence, I then compute the cross-state trade barriers in India.

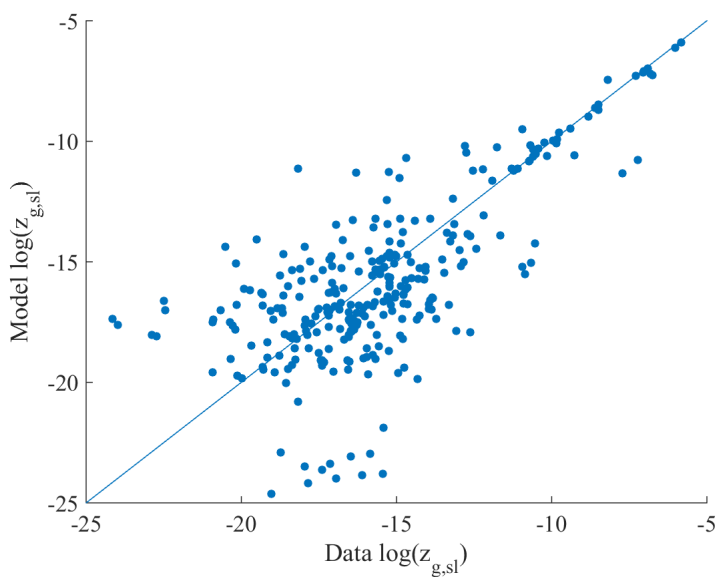

(a) Agriculture: corr $=0.73$

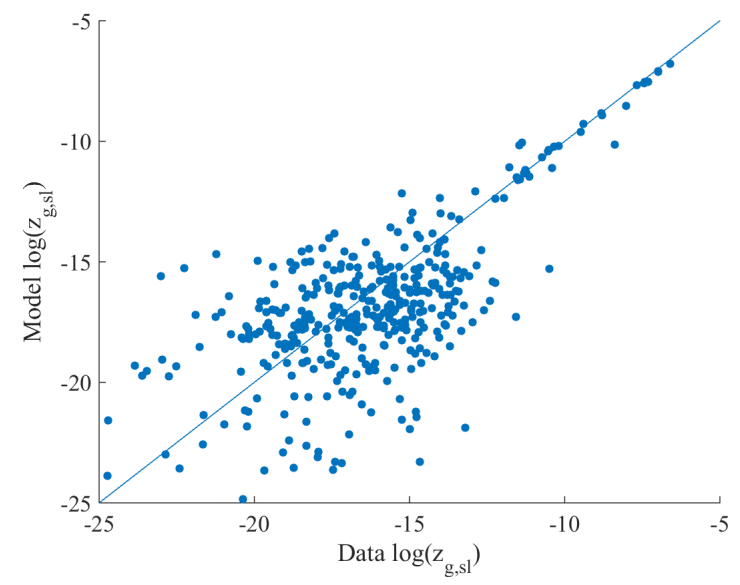

(b) Manufacturing: corr $=0.67$

Figure A.2: Indian Domestic Trade 


\section{A.7 Welfare}

Welfare is measured as a compensating differential: by how much does the wage in each region need to change in order to receive the same utility in the baseline as in the counterfactual? Total state utility is given by equation (10). Recall that a representative agent in region $r$ in state $s$ chooses the quantity consumed of both agricultural and manufacturing goods of variety $j_{g}$, denoted by $\left\{q\left(j_{g}\right)\right\}_{j_{g} \in[0,1]}, g \in\{a, m\}$ to maximize

$$
\max _{q_{s}^{r}\left(j_{a}\right) \geq 0, q_{s}^{r}\left(j_{m}\right) \geq 0}\left(\frac{\sigma_{a}}{\sigma_{a}-1}\right) \int_{0}^{1}\left[q_{s}^{r}\left(j_{a}\right)^{\frac{\sigma_{a}-1}{\sigma_{1}}}\right] d j_{a}+\left(\frac{\sigma_{m}}{\sigma_{m}-1}\right) \int_{0}^{1}\left[q_{s}^{r}\left(j_{m}\right)^{\frac{\sigma_{m}-1}{\sigma_{m}}}\right] d j_{m}
$$

subject to

$$
\int_{0}^{1} q_{s}^{r}\left(j_{a}\right) p_{s}^{r}\left(j_{a}\right) d j_{a}+\int_{0}^{1} q_{s}^{r}\left(j_{m}\right) p_{s}^{r}\left(j_{m}\right) d j_{m}=w_{s}^{r}
$$

The first-order necessary conditions are given by

$$
\begin{aligned}
q_{s}^{r}\left(j_{a}\right)^{\frac{\sigma_{a}-1}{\sigma_{a}}-1} & =\lambda_{s}^{r} p_{s}^{r}\left(j_{a}\right) \\
q_{s}^{r}\left(j_{m}\right)^{\frac{\sigma_{m}-1}{\sigma_{m}}-1} & =\lambda_{s}^{r} p_{s}^{r}\left(j_{m}\right) \\
\int_{0}^{1} q_{s}^{r}\left(j_{a}\right) p_{s}^{r}\left(j_{a}\right) d j_{a}+\int_{0}^{1} q_{s}^{r}\left(j_{m}\right) p_{s}^{r}\left(j_{m}\right) d j_{m} & =w_{s}^{r} .
\end{aligned}
$$

Multiplying the first two first-order necessary conditions by $q_{s}^{r}\left(j_{a}\right)$ implies

$$
\begin{aligned}
q_{s}^{r}\left(j_{a}\right)^{\frac{\sigma_{a}-1}{\sigma_{a}}} & =\lambda_{s}^{r} p_{s}^{r}\left(j_{a}\right) q_{s}^{r}\left(j_{a}\right) \\
q_{s}^{r}\left(j_{m}\right)^{\frac{\sigma_{m}-1}{\sigma_{m}}} & =\lambda_{s}^{r} p_{s}^{r}\left(j_{m}\right) q_{s}^{r}\left(j_{m}\right) \\
\int_{0}^{1} q_{s}^{r}\left(j_{a}\right) p_{s}^{r}\left(j_{a}\right) d j_{a}+\int_{0}^{1} q_{s}^{r}\left(j_{m}\right) p_{s}^{r}\left(j_{m}\right) d j_{m} & =w_{s}^{r} .
\end{aligned}
$$


Then, integrating the first two expressions over all varieties implies

$$
\begin{aligned}
& \int_{0}^{1} q_{s}^{r}\left(j_{a}\right)^{\frac{\sigma_{a}-1}{\sigma_{a}}} d j_{a}=\lambda_{s}^{r} \int_{0}^{1} p_{s}^{r}\left(j_{a}\right) q_{s}^{r}\left(j_{a}\right) d j_{a} \\
& \int_{0}^{1} q_{s}^{r}\left(j_{m}\right)^{\frac{\sigma_{m}-1}{\sigma_{m}}} d j_{m}=\lambda_{s}^{r} \int_{0}^{1} p_{s}^{r}\left(j_{m}\right) q_{s}^{r}\left(j_{m}\right) d j_{m} \\
& \int_{0}^{1} q_{s}^{r}\left(j_{a}\right) p_{s}^{r}\left(j_{a}\right) d j_{a}+\int_{0}^{1} q_{s}^{r}\left(j_{m}\right) p_{s}^{r}\left(j_{m}\right) d j_{m}=w_{s}^{r} .
\end{aligned}
$$

Substitute these expressions into the objective function in order to obtain the indirect utility at the state level:

$$
\begin{aligned}
U_{s} & =\lambda_{s}^{r}\left[\left(\frac{\sigma_{a}}{\sigma_{a}-1}\right) \int_{0}^{1} q_{s}^{r}\left(j_{a}\right) p_{s}^{r}\left(j_{a}\right) d j_{a}+\left(\frac{\sigma_{m}}{\sigma_{m}-1}\right) \int_{0}^{1} q_{s}^{r}\left(j_{m}\right) p_{s}^{r}\left(j_{m}\right) d j_{m}\right] \\
& =\lambda_{s}^{r}\left[\left(\frac{\sigma_{a}}{\sigma_{a}-1}\right) x_{s, a}^{r}+\left(\frac{\sigma_{m}}{\sigma_{m}-1}\right) x_{s, m}^{r}\right],
\end{aligned}
$$

where

$$
x_{s, g}^{r}=\int_{0}^{1} q_{s}^{r}\left(j_{g}\right) p_{s}^{r}\left(j_{g}\right) d j_{g}
$$

is defined as the state- and region-specific expenditure on good variety $j_{g}$. 